\title{
GUIDELINES FOR NIST STANDARDS COMMITTEE PARTICIPANTS
}

\section{JoAnne Overman James Rountree}

\author{
U.S. DEPARTMENT OF COMMERCE \\ Natlonal Instltute of Standards \\ and Technology \\ Office of Standards Servlces \\ Office of Standards Code \\ and Information \\ Galthersburg, MD 20899
}

Prepared by U.S. DEPARTMENT OF COMMERCE Natlonal Instltute of Standards and Technology Office of Standards Servlces Galthersburg, MD 20899

Raymond G. Kammer, Acting Director

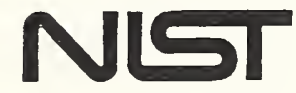





\section{GUIDELINES FOR NIST STANDARDS COMMITTEE PARTICIPANTS}

\section{JoAnne Overman James Rountree}

U.S. DEPARTMENT OF COMMERCE National Institute of Standards and Technology Office of Standards Services Offlce of Standards Code and Information

Galthersburg, MD 20899

\section{Prepared by} U.S. DEPARTMENT OF COMMERCE Natlonal Institute of standards and Technology Offlce of Standards Servlces Galthersburg, MD 20899

October 1989

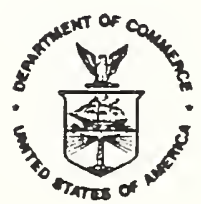

U.S. DEPARTMENT OF COMMERCE Robert A. Mosbacher, Secretary NATIONAL INSTITUTE OF STANDARDS AND TECHNOLOGY

Raymond G. Kammer, Acting Director 


\section{PREFACE}

This document provides guidance to NIST employees related to their participation in voluntary standards development activities of standards bodies. The information herein reflects Federal policy as stated in office of Management and Budget circular $A-119$, as well as NIST policy relating to voluntary standards activities.

These guidelines, a revision of those issued in December 1984, was prepared by the office of standards Services, which is the NIST organization responsible for formulating and implementing Federal government standards policy.

NIST employees who participate in standards activities should be familiar with these guidelines, along with the several documents in the appendices. NIST managers should assure that NIST staff follow these guidelines in their standards work.

Suggestions for improvements, comments, or questions relating to the contents of this document should be forwarded to the office of standards Services. 


$$
\text { , }
$$


TABLE OF CONTENTS

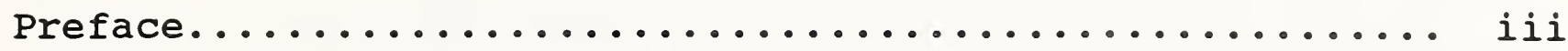

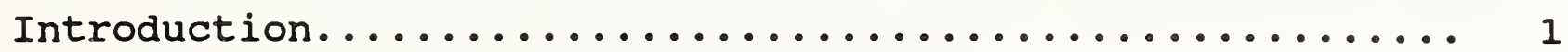

Appointment to a standards Committee................. 1

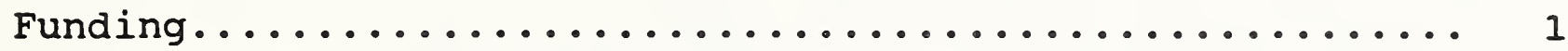

Responsibilities of NIST Representatives on Standards

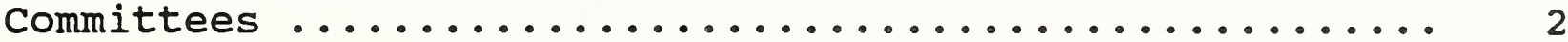

National Center for Standards and Certification

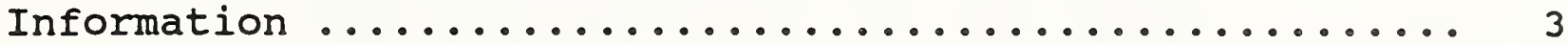

Related Documents $\ldots \ldots \ldots \ldots \ldots \ldots \ldots \ldots \ldots \ldots \ldots \ldots$

Appendices

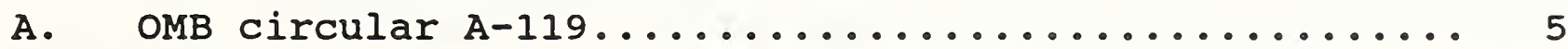

B Administrative Manual Subchapter $3.02 \ldots \ldots \ldots \ldots \ldots$

C. Administrative Manual subchapter $3.03 \ldots \ldots . . . . .19$

D. Title IV of the Trade Agreements Act of $1979 \ldots \ldots \ldots 23$

E. Guidelines for Participation by U.S. Government Agencies, Employees, or Representatives in International standards-Related Activities ....... 31

F. NIST Form 83, Record of Committee Assignment ....... 41 


\section{INTRODUCTION}

NIST has participated in standards activities since the early 1900's. Through standards participation, staff are able to contribute technical expertise and to gain valuable information relating to industry practices and needs, thus contributing to the planning of NIST research programs.

OMB Circular No. A-119, "Federal Participation in the Development and Use of Voluntary Standards," states that "when properly conducted, standards development can increase productivity and efficiency in industry, expand opportunities for international trade, conserve resources, and improve health and safety." It also notes that standards activities, "if improperly conducted, can suppress free and fair competition, impede innovation and technical progress, exclude safer and less expensive products, or otherwise adversely affect trade, commerce, health or safety."

Because standards have a significant effect in the marketplace, participants in standardization committee activities have specific responsibilities in the standards development process, as well as their general obligations as Federal employees (see Appendix E).

Participants are encouraged to contact the office of standards Services of NIST for any additional information or assistance they may need for their standards activity.

\section{APPOINTMENT TO A STANDARDS COMMITTEE}

The decision that an employee should participate on a standards committee is made by management based on unit mission and goals, resource commitments, and technical competence required. NIST requires that standards committee participants complete and have their supervisor approve, NIST Form 83, Record of Committee Assignment. These forms are to be submitted for processing by the staff of the Standards Assistance and Management Information (SAMI) project, which serves as the NIST standards and Professional Committee Monitoring office.

\section{FUNDING}

When an employee participates in a standards activity, the cost is normally paid by the organizational unit at NIST or another Federal agency. Federal funds may not be used to pay an individual's membership fees. However, NIST does pay certain administrative and organizational fees. 


\section{RESPONSIBILITIES OF NIST REPRESENTATIVES ON STANDARDS COMMITTEES}

\section{Keep Management Informed}

Standards committee participants are to keep their supervisor informed, especially where there are other NIST representatives and coordination of viewpoints is necessary or desirable. Participants are to seek the help and advice of NIST's office of standards services on policy and procedural matters and submit completed NIST Form 83 for each committee membership.

\section{Coordinate with Federal Participants}

Participants should interact with other Federal agency committee members. OMB Circular A-119 states that "when two or more agencies participate in a given voluntary standards body or standards-developing group, their representatives should coordinate views on matters of paramount importance so as to present a single, unified position."

\section{Report "High-Impact" Issues}

NIST has adopted specific recommendations for identifying sensitive standards-related issues to be brought to the attention of the Director, office of standards Services and the MOU Director. An issue is considered to be "high-impact" if it meets any of the following criteria:

- It may be brought to the attention of the NIST Director or the secretary of commerce by one or more outside groups, such as the Congress, another Federal agency, a trade association, an industrial firm, or an influential individual.

- It entails broad coordination across internal NIST operating units or agency boundaries.

- It generates a need for policy guidance regarding appropriate limits of NIST responsibility, whether technical or financial.

- There is the potential for outside criticism of NIST by reputable persons or organizations.

- It would have significant impact on the United states' international trade.

\section{Encourage Innovation}

Participants should encourage development and use of performance standards. The use of performance criteria in standards will generally encourage innovation. On the other hand, design specifications, or the inclusion of a patented device, material or process, might unnecessarily limit technical progress. 


\section{Consider International Standardization}

Participants should be aware of international standards and standardization activities related to their national standards committee work. The United States is obligated under the Trade Agreements Act of 1979 to adopt international standards where appropriate. Participants should also be mindful of seeking to incorporate U.S. standards principles in international standards.

\section{Know the Rules}

Participants should familiarize themselves with the scope of the standards committee and the standards body's policies and procedures. The use or abuse by participants in standards committee activities of standards procedures to restrict competition is improper and violates various Federal and state antitrust statutes. Participants involved in violations of those statutes are subject to civil and criminal prosecution.

\section{Keep Records}

Participants should maintain a file of committee-related information including the committee by-laws, current membership list, minutes of committee meetings, final ballots, and relevant correspondence. This file should be retained by the participants or the unit for at least 5 years after the conclusion of the standards activity.

\section{NATIONAL CENTER FOR STANDARDS AND CERTIFICATION INFORMATION}

The Office of Standards Services operates the National Center for Standards and Certification Information, which maintains a reference collection of standards, specifications and codes published by U.S. professional and technical societies, Government agencies, and major national and international bodies. The collection also contains articles, pamphlets, reports and handbooks on standardization along with foreign and domestic periodicals and newsletters published by standards organizations. The Center staff can assist in identifying relevant U.S., foreign or international standards in a given product or subject area.

\section{RELATED DOCUMENTS}

The following documents are available upon request:

Directory of DoC staff Memberships on outside standards Committees - an annual listing of Department of Commerce staff memberships by name and standards-developing organization

Directory of International and Regional organizations conducting Standards-Related Activities - NIST Special Publication 767

Standards Activities of Organizations in the United States - NBS Special Publication 681 (under revision) 
Standards Committee Activities of NIST - an annual report describing Institute contributions in standards activities.

For additional information on committee participation, contact:

$$
\begin{gathered}
\text { Office of Standards Services } \\
\text { Admin. Bldg., Room A629 } \\
\text { Gaithersburg, MD } 20899 \\
\text { (301) } 975-4035
\end{gathered}
$$


APPENDIX A

OMB CIRCULAR A-119, "FEDERAL PARTICIPATION IN THE DEVELOPMENT AND USE OF VOLUNTARY STANDARDS" 
held November 15, 1982, from 9:00 8.m. to 5:00 p.m. and November 16 to 20,1982 from 9:00 a.m. to 5:30 p.m., in the 11th floor reception area of the Columbia Plaz.a Office Complex, 2401 E Street. NW., Washington, D.C., 20506.

This meeting is for the purpose of panel review, discussion, evaluation, and recommendation on applications for financial assistance under the National Foundation on the Arts and the Humanities Act of 1965, as amended. including discussion of information given in confidence to the agency by grant applicants. In accordance with the determination of the Chairman published in the Federal Register of February 13, 1980, these sessions will be closed to the public pursuant to subsections (c)(4). (6) and $9(b)$ of section $552 b$ of Title 5, United States Code.

Further information with reference to this meeting can be obtained from Mr. John H. Clark. Advisory Committee Management Officer, National Endowment for the Arts, Washington, D.C. 20506, or call (202) 634-6070.

John H. Clark.

Director. Office of Council and Panel Operations. National Endowmenl for the Arts. October 21. 1982

[FR Doc. 22-30001 Filed 10-20-22:8:45 am] ALUNO COOE 7537-01-M

OFFICE OF MANAGEMENT AND BUDGET

Issuance of Circular No. A-119, "Federal Particlpation In the Development and Use of Voluntary Standards"

AQENCY: Office of Management and Budget.

ACTION: Final Issuance of OMB Circular No. A-119, "Federal Participation in the Development and Use of Voluntary Standards."

sUmmary: This OMB Circular provides policy and administrative guidance to Federal agencies on using voluntary standards for procurement and regulatory purposes, on participating with private sector organizations to develop such standards, and coordinating Executive Branch participation in the development of voluntary standards. Implementation of this Circular is experted to result in reduced costs to the Government in developing and maintaining standards for products, systems and services.

effective Date: This Circular, which supersedes OMB Circular No. A-119. dated January 17,1980 , is effective upon publication.
FOR FUATHER INFORMATION CONTACT:

David F. Baker, Office of Federal

Procurement Policy, Office of

Management and Budget, Washington,

DC 20503 (202) 395-7207.

SUPPLEMENTAAY INFORMATION: On ApRII 21, 1982, the Office of Management and Budget published a draft Circular. subject as above, for a 60-day period of public and agency comment. Comments were received from more than 120 individuals and organizations, including Federal agencies, business firms, industry associations, professional groups and private citizens.

There follows a summary of the major comments grouped by subject and a response to each-including a brief description of changes made as a result of the comments. Many other changes of a less significant character were made to increase clarity, simplicity, precision and readibility, and to reduce the burdens of compliance as much as possible.

\section{A. Procedural Criteria Imposed on Standards Devolopers}

Ccinment: Several commenters objected to OMB's deletion of specific procedural criteria which the previous version of the Circular imposed on voluntary standards bodies as a precondition to Federal participation. They argued that such criteriaintended to increase public participation and openness-would help to minimize the potential for anti-trust activities. Other commenters suggested that while such procedures should not be mandatorily imposed, OMB should instruct agencies to encourage private standards developers to follow such procedures.

Response: With regard to the inclusion of procedural criteria and their mandatory imposition on standard developers, we have concluded that imposition of the mandatory procedures contained in the previous edition of the Circular is inappropriate, burdensome and costly and that the question of imposing such criteria is peripher il to the fundamental aims of the Circular. We do agree that, as with any human endeavor, the voluntary standards developinent process is vulnerable to abuse. Consequently, we have cautioned Federal agencies to beware of such potential (Para. 7). We have also provided guidance to agencies in the form of a letter from the Department of Justice, dated June 22, 1982, which discusses sugsested agency approaches to the question of public participation in private sector standards development.

\section{B. Regulatory Applications}

Comment: Some commenters suggested that the Circular should be limited to procurement applications, and that Federal agencies should not be required to use voluntary standards for regulatory purposes. Some commenters suggested, in addition, that the Circular should not apply to "independent regulatory agencies".

Response: We believe the benefits to be derived from the procurement use of standards are equally valid for regulatory applications-particularly the benefits of assuring private sector input into Federal regulatory activities while reducing the potential for duplicating existing, adequate voluntary standards with Government standards. With regard to the second concern, the Circular does not "require" Federal agencies to use voluntary standards for regulatory purposes. It establishes a policy preference in that regard but leaves to the agencies, themselves, the decision as to whether to adopt a given voluntary standard for a specific Federal regulatory purpose. (The legal requirements associated with such adoption, such as those of the Administrative Procedures Act, will, of course, continue to apply.) We believe such an approach is entirely appropriate with respect to independent regulatory agencies as with the rest of the Executive Branch.

\section{Role of the Department of Commerce}

Comment: Several commenters objected to the requirements that the Department of Commerce maintain listings of (1) voluntary and Government standards, (2) voluntary standards bodies, and (3) those standards organizations with which Federal agencies interact - on the grounds that this would result in extensive and costly reporting requirements. Other commenters suggested that the agency reporting requirements contained in the Circular were, themselves, overly burdensome.

Response: We agree. The requirements to maintain various listings have been eliminated. The provisions dealing with reports on agency implementation of the Circular have been revised to require that reports be summary, as opposed to detalled, in nature.

\section{Voluntary Dispute Resolution Service}

Comment: Some commenters objected to our deletion of the requirement that the Department of Commerce establish a program to make available a "voluntary dispute resolution service" to handle precedural complaints brought by 
interested parties against voluntary standards bodies. Those commenters suggested that such a mechanism would provide an impartial means of resolving standards disputes without costly and lengthy litigation.

Response: While we take no position on the substantive merits of such a mechanism. we are satisfied that the requirement to establish such a service is not an appropriate element for inclusion in this Circular. Agencies with mission concerns in this area (e.8. Commerce, Justice, etc.) may, of course. consider establishing such a service as it is within their province to do so. The creation of the mechanism is clearly peripheral to the policy issues dealt with in the Circular, however. which are limited to Federal participation in the development and use of voluntary standards.

\section{E. Single Federal Position}

Comment: Many commenters susgested that the provisions of the Circular that required agencies to coordinate their views and express a single Federal position in private sector standards development activities were unnecessary and unworkable - and that establishment of a mechanism to achieve these purposes would be costly and lead to lengthy delays in the standards development process.

Response: We continue to believe that agencies should endeavor to coordinate their views and present single Federal positions in matters of paramount importance. We agree, however, that the requirement to do 80 in all such instances is unreasonable and could lead to bureaucratic delays.

Consequently, we have eliminated the requirement that Federal positions must be developed in all instances, as well as those provisions which would have required the Secretary of Commerce to appoint a "lead" agency when disagreements as to the nature of the Government's position occurred on a given issue. We continue to expect agency representatives to make a reasonable effort to present a single Federal position reflective of the public interest on matters on paramount interest in those standards activities wherein two or more agencies participate.

Candice C. Bryant.

Acting Deputy Assistant. Directar far Administrotion.

\section{Executive Office of the President}

Office of Management and Budget

October 26. 1982.

Memorandum to Heads of Executive

Departments and Agencies

From: David A. Stockman
Subjecl: OMB Circular No. A-119. "Federal

Participation in the Development and Use of Voluntary Slandards"

Allached. for your implementation. is a revision to OMB Circular No. A-119 which provides guidance to agencies in working with. and using the products of. private sector standards organizations. The effect of this revision is to eliminate the costly.

unnecessary, and burdensome aspects of the Circular. while continuing to encourage agency participation in the development of private sector standards.

Also altached for your information and use is a letter. dated June 22. 1982. from the Department of Justice, which provides guidance in the implementation of the Circular-particularly as it relates to working with private sector groups to develop needed standards.

\section{Executive Office of the President}

Office of Manogement and Budget

October 26. 1882.

\section{Circular No. A-118-Rovieod}

To the Heads of Executive Departments and Establishments

Subject: Federal Participation in the Development and Use of Voluntary Standards

1. Purpase. This Circular establishes policy to be followed by executive agencies in working with voluntary standards bodies. It also establishes policy to be followed by executive branch agencies in edopting and using voluntary standards.

2. Rescissians. This Circular supersedes OMB Circular No. A-119, dated January 17. 1980. which is rescinded.

3. Background. Many Governmental functions involve products or services that must meet reliable standards. Many such standards, appropriate or adaptable for the Government's purposes, are available from private voluntary standards bodies. Government participation in the standardsrelated activities of these voluntary bodies provides incentives and opportunities to establish standards that serve national needs, and the adoption of voluntary standards. whenever practicable and appropriate. eliminates the cost to the Government of developing its own standards. Adoption of such standards also furthers the policy of reliance upon the private sector to supply Government needs for goods and services, as enunciated in OMB Circular No. A-78.

4. Applicability. This Circular applies to all executive agency participation in voluntary standards activities. domestic and international, but not to activities carried out pursuant to treaties and international standardization agreements.

5. Definitions. As used in this Circular:

a. Executive agency (hereinafter referred to as "agency") means any execulive

department, independent commission, board. bureau. office. agency. Government-owned or-controlled corporation or other establishment of the Federal Government. including regulatory commission or board. It does not include the legislative or judicial branches of the Federal Government. b. Slandard means a prescribed set of rules. conditions. or requiremenis concerned with the definition of terms: classificalion of components: delineation of procedures: specification of dimensions. malerials. performance. design. or operations: measurement of quality and quantily in describing materials. products. systems. services. or practices; or descriptions of fit and measurement of size.

c. Voluntary standords are established generally by private sector bodies and are available for use by any person or organization. private or governmental. the term includes what are commonly referred to as "industry standards" as weil as "consensus standards", but does not include professional standarde of personal conduct. institutional codes of ethics, private standards of individual firms, or standards mandated by law, such ss those contained in the United States Pharmacopela and the National Formulary. as referenced in 21 U.S.C. 351

d. Government standards include individual agency standards and specifications as well as Federal and Military standards and specifications.

e. Valuntary standards bodies are private sector domestic or multinational organizations-such as nonprofit organizations, industry associations. professional and technical societies. institutes. or groups, and recognized test laboratories-that plan. develop, eutablish. or coordinate voluntary standards.

f. Standards-develaping groups are committees. boards. or any other principal subdivisions of voluntary standards bodies. established by such bodies for the purpose of developing, revising. or reviewing standards. and which are bouno by the procedures of those bodies.

8. Adaption means the use of the latest edition of a voluntary standard in whole, in part. or by reference for procurement purposes and the inctusion of the latest edition of a voluntary standard in whole, in part, or by reference in regulation(s).

h. Secretary means the Secretary of Commerce or that Secretary's designee.

6. Policy. It is the policy of the Federal Government in its procurement and regulatory activities to:

a. Rely on voluntary standards, both domestic and international, whenever feasible and consistent with law and regulation pursuant to law:

b. Participate in voluntary standards bodies when such particlpation is in the public interest and is compatible with agencies missions, authorities, priorities, and budget resources; and

c. Coordinate agency participation in voluntary standards bodies so that (1) the most effective use is made of agency resources and representatives; and (2) the views expressed by such representatives are in the public Interest and, as a minimum, do not conflict with the interests and established views of the agencies.

-7. Policy Guidelines. In implementing the policy established by this Circular, agencies should recognize the positive contribution of standards development and related activities. 
When properly conducted, standards develnpment can increase productivity and efficiency in industry. expand opportunities for international trade. conserve resources. and improve health and safety. It also must be recognized. however. that these activities. if improperly conducted. can suppress free and fair competition, impede innovation and technical prosess, exclude safer and less expensive products, or otherwise adversely affect trade, commerce, health, or safety. Full account shall be taken of the impact on the economy, applicable Federal laws. policies. and national objectives, including, for example. laws and regulations relating to antitrust. national security. small business. product safety. environment. technological development, and conflicts of interest. It should also be noted. however, that the provisions of this Circular are intended for internal management purposes only and are not intended to (1) create delay in the administrative process, (2) provide new grounds for judicial review, or (3) create legal rights enforceable against agencies or their officers. The following policy guidelines are provided to assist and govern implementation of the policy enunciated in paragraph 6 .

a. Reliance on Voluntary Standards. (1) 'Voluntary standards that will serve agencies' purposes and are consistent with applicable laws and regulations should be adopted and used by Federal agencies in the interests of greater economy and efficiency, unless they are speciffcally prohibited by law from doing so.

(2) Voluntary standards should be given preference over non-mandatory Government standards unless use of such voluntary standards would adversely affect performance or cost, reduce competition, or have other significant disadvantages. Agencies responsible for developing Government standards should review their existing standards at least every five years and cancel those for which an adequate and appropriate voluntary standard can be substituted.

(3) In adopting and using voluntary standards, preference should be given to those based on performance criteria when such criteria may reasonably be used in liev of design. material, or construction criteria.

(4) Voluntary standards adopted by Federal agencies should be referenced, alons with their dates of issuance and sources of availability, in appropriate publications. regulatory orders, and related in-house documents. Such adoption should take into account the requirements of copyright and other similar restrictions.

(5) Agencies should not be inhibited, if within their statutory authorities. from developing and using Government standards in the event that voluntary standards bodies cannot or do not develop a needed. acceptable standard in a timely fashion. Nor should the policy contained in this Circular be construed to commit any agency to the use of a voluntary standard which, after due consideration, is, in its opinion, inadequate. does not meet statutory criteria, or is otherwise inappropriate.

b. Participation in Voluntory Slandards Bodies. (1) Participation by knowledgeable agency employees in the standards activities of voluntary standards bodies and standards. developing groups should be actively encouraged and promoted by agency officials when consistent with the provisions of paragraph $6 b$.

(2) Agency employees who, at Government expense. participate in standards activities of voluntary standards bodies and standards.

developing groups should do so as specificaliy authorized agency

representatives.

(3) Agency participation in voluntary standards bodies and standards-developing groups does not. of itself, connote agency agreement with, or endorsement of. decisions reached by such bodies and groups or of standards approved and published by voluntary standurds bodies.

(4) Participation by agency representatives should be aimed at contributing to the development of voluntary standards that will eliminate the necessity for development or maintenance of separate Government standards.

(5) Agency representatives serving as members of standards-developing groups should participate actively and on a basis of equality with private sector representatives. In doing so, agency representatives should not seek to dominate such groups. Active participation is intended to include full involvement in discussions and techical debates, registering of opinions and, if selected, serving as chairpersons or in other official capscities. Agency representatives may vote, in accordance with the procedures of the volustary standards body, at each stage of standards development, unless specifically prohibited from doing so by law or their agencies.

(6) The number of individual agency participants in a given voluntary standards activity should be kept to the minimum required for effective presentation of the various program, technical, or other concerns of Federal agencies.

(7) The providing of Agency support to a voluntary standards activity should be limited to that which is clearly in furtherance of an agency's mission and responsibility. Normally, the total amount of Federal support should be no greater than that of all private sector participants in that activity except when it is in the direct and predominant interest of the Government to develop a standard or revision thereto and its development appears unlikely in the absence of such support. The form of agency support. subject to legal and budgetary authority, may include:

(a) Direct financial support; e.g. grants. sustaining memberships, and contracts:

(b) Administrative support; e.g.. travel costs, hosting of meetings, and secretarial functions:

(c) Technical support: e.g., cooperative testing for standards evaluation and participation of agency personnel in the activities of standards-developing groups: and

(d) Joint planning with voluntary standards bodies to facilitate a coordinated effort in identifying and developing needed standards.

(8) Participation by agency representatives in the policymaking process of voluntary standards boties, in accordance with the procedures of those bodies. is encouragedparticularly in matters such as establishing priorities. developing procedures for preparing. reviewing. and approving standards, and creating standards-developing groups. In order to maintain the private. nongovernmental nature of such bodies. however, agency representatives should refrain from decisionmaking involvement in the internal day-to-day management of such bodies (e.g. selection of salaried officers and employees, establishment of staff salaries and administrative policies).

(9) This Circular does not provide guidance concerning the internal operating procedures that may be applicable to voluntary standards bodies because of their relationships to agencies under this Circular. Agencies should, however, carefully consider what laws or rules may apply in particular instance because of these relationships. For example, these relationships may involve the Federal Advisory Committee Act, as amended (5 U.S.C. App. 1), or a provision of an authorizing statute for a particular agency. Agencies are best able to determine what laws and policies should govem particular relationships and to assess the extent to which competition may be enhanced and cost-effectiveness increased. Questions relating to anti-trust implications of such relationships should be addressed to the Altomey General.

8. Responsibilities. a. The Secretary will:

(1) Coordinate and foster executive branch implementation of the policy in paragraph 6 of this Circular, and may provide administrative guidance to assist agencies in implementing paragraph 8.b. (5) of this

Circular

(2) Establish an interagency consultative mechanism to advise the Secretary and agency heads in implementing the policy contained herein. That mechanism shall provide for participation by all affected agencies and ensure that their views are considered; and

(3) Report to the Office of Management and Budget concerning implementation of this

Circular.

b. The heads of agencies concerned with standards will:

(1) Implement the policy in paragraph 6 of this Circular in accordance with the policy guidelines in paragraph 7 within 120 days of issuance:

(2) Establish procedures to ensure that agency representatives participating in voluntary standards bodies and standardsdeveloping groups will, to the extent possible. ascertain the views of the agency on matters of paramount interest and will, as a minimum. express views that are not inconsistent or in conflict with established agency views;

(3) Endeavor, when two or more agencies participate in a given voluntary standards body or standards-jeveloping group, to coordinate their views on matters of paramount importance so as to present. whenever feasible, a single unified position.

(4) Cooperate with the Secretary in carrying out his responsibilities under this Circular, and 
(5) Consult with the Secretary. as necessary. In the development and issuance of. internal agency procedures and guidance Implementing this Circtiar, and submith in response to the request of the Secretary. summary reports on the status of egency interaction with voluntary standerds bodiea.

9. Reporting Requirementa. Three year from the date of issuance of this Circular, and each thind year thereafier, the Secretary will submit ts the Office of Management and Budget a brief summary report on $L$ e status of agency loteraction with voluntary standards bodiea. As a minimum, the report will Include the following triormation.

a. The anture and extent of agency participation in the development and utilization of voluntary standarde; and

b. An evaluation of the effoctivenese of the policy promulgated is this Circular and recommendations of change.

10. Policy Review. The pollicy contained in this Circular shall be reviewed for effectivenese by the Office of Management and Budget three years from the date of issuance.

11. Inquiries. For trformation concerning this Circular, contact the Office of Management and Budget, Office of Foderai Procurement Pollicyptelephone 202/385-7200. David A. Stockman.

Diroctor.

Department of Juatice

\section{Antitrust Division}

Office of the Assistont Attomey General

June $22,2982$.

Mr. Donald B. Sowle.

Administrator for Federal Procurement Policy

Offlice of Management and Budget

Wasbington, D.C. 20503

Dear Mr. Sowle: I am writing to exprese the views of the Department of justice on competition policy lesues reised by the Revised OMB Circular No. A-119, "Federil Participation in the Development and Use of Voluntary Standards" published for comment In the Foderal Rogietes on April 29, 1982 (47) Fed. Rez 16, 919).

In our comments on previous drafte of the Circular, dated December 20, 1970 and June 13. 1972, we have supported a policy of federal adoption of privately developed standards when appropriate. Through particlpation in, and support for, private tandards making activities, agencies may benefit greatly from private expertise and will avold the wasteful duplication of cost and effort involved in developing their own in-house standards. The Department of Justice is not opposed to the policy announced in Revised OMB Clrcular A-119. which would eliminate the rigid "due procese" precondition to federal participation in private standarde activities Such a precondition is overly restrictive, since as a practical matter federal agencies will often be required to adopt the standards developed regardless of federal participation in their development. Thue, in our view, the better solution is to participate in standards setting bodies and work within them to assure that upprapriate procedures ere adopled.
The Department belleves that federal participants should encourage the adoption of procedures to foster access to standand setting activities and traneparency in such activities. Such procedures facilltate the development of standards acceptable to the entire affected industry as well as to consumers. In particular, notice and opportunity for comment help aseure that atandards will be besed on adequate Information as to their utility and consequences. Moreover. It is especislly important that performance criteria be given - prominent perhepe predominant plece in eny standards activity. Foderel agency representativee, therefore, should advocate. as strongly as possible, procedures designed to aseure that a broad range of Information is collicited and that performance criteria are central elements of the resulting standarda.

In addition to the prectical adventages of open standards proceedinge, euch eafogund would mitigate the eubstantial

enticompetitive potental inherent in private standards groupe. The importance of assuring edequate consideration of competition in the work of private standards bodies wes noted recently by the Supreme Court in American Society of Mechanical Engineers, Ina v. Hydrolevel Corp. The case involved a product etandard which bed been adopted in 40 states and all but one of the Canadian provinces. The Court obeerved that organizations creating such standards could be "tife with opportunities for enticompettive activity." Foderal asencies ought to strongly encourage these private groups to ensure consideration of all relevant viewpolnts and tinterests tncluding those of conoumers, and potential or existing indurtry participanta.

This country's international obligations and policy, as expreseed in the Standerds Code negotiated during the Tokyo Round of the Multilateral Trade Negotiations, see the Agreement on Technical Barriers to Trade. codified at 19 U.S.C. 2531 ot seg. (1900), provide another important reacon for federal agency partlcipants to excourage the adoption of open procedures for private standards groupe. This Code, approved by Congreas as well as by our leading trading partners, seeks to provent the creation of product standerds which discriminate againat import competition. It requires central sovernmental bodies to provide notice and opportunity to comment in their own standards making activitien and encourages goveraments to take reasonable measures to ensure that non-govermmental bodies provide indlar protection. Where the federal govermment is in fact involved in the private group, the obligations of the Standards Code would appear even stronger. Open procedures opecifically adequate botice and opportunlty to comment, would further the objectives of the Standards Code, and would substantially reduce the possibility that diecriminatory, anticompetitive standards will be developed.

The Circular would encourage use of voluntary standards for regulatory and other purposes. N though we applaud this expantion of the scope of the Circular, :ve believe that 'رroadened federal use of privately developed standarde shoulc be accompanied with broad federal awareness of the practical and competituve advantages of lndustry-wide access to private standards bodies. Such access is an asset to federal participation in private atandarde activities. but it is aleo of great importance when federal agencies. without participation in the procese, merely adopt standards for procurement or regulatory use.

As we indicated in our previous comments. private activity is nol by virtue of governmental participation or approvel. ahielded from the antitruat lawe. Federal agency participation in a standarde body. however, may imply federal approvel of the process and of the resulting standard, and pertape lead private participants to become lex in their own entitruat ecrutiny. To diepel any false impreselone federal agency representatives abould inform private partlcipants that federal perticipation does not remove entitrust concerne as well as advocate that appropriate procedures be employed in the standards proceedinga.

Sincerely youre.

Ronald G. Carr.

Acting Assistant Attomey General, Antitust Division.

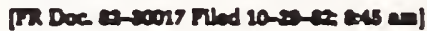

cum cos s1x-1:

\section{SECURTITES AMD EXCHANGE COMMISSION}

\section{[Rel Ma 12750; 012-6298]}

\section{Daly Tx Fres fncoms Fund, Ince; Fining of en Applieation}

October 19,1922

Notice is bereby given that Daily Tax Free Income Fund, Inc, 100 Park Avenue, New York, N.Y. 10017 (the "Applicant"), registered under the Investment Company Act of 1940 ("Act") as an open-end, diversified. management investment company, filed an application on August 6, 1882, and an amendment thereto on October 18, 1982. requesting an order of the Commiailon. purwuant to Section $6(c)$ of the Act, exempting Applicant and any additional separate portfolios that may be established by Applicant in the future. from the provisions of Section 2(a)(41) of the Act and Rules 20-1 and 220-1 under the Act to the extent necessary to permit Applicant to value its assets using the amortized cost method of valuation. All interested persons are referred to the application on file with the Commission for a statement of the representations contained therein, which are summarized below.

Applicant states that it was organized as a corporation under the laws of Maryland on July 22, 1882, and that it registered under the Act on July 22, 1982. Although it will have initially only one investment portfolio the Board of 


\section{APPENDIX B}

ADMINISTRATIVE MANUAL SUBCHAPTER 3.02 "STANDARDS AND PROFESSIONAL COMMITTEES" 



\begin{tabular}{|c|c|c|c|}
\hline $\begin{array}{l}\text { U. S. DEPARTMENT OF COMMERCE } \\
\text { NATOOWU NSTIUTE OF STANOAFOS MO TECANOLOGY }\end{array}$ & Chapter & 3 & Commlttees \\
\hline $\begin{array}{c}\text { ADMINISTRATIVE } \\
\text { MANUAL }\end{array}$ & Subchapter & 3.02 & $\begin{array}{l}\text { Standards and } \\
\text { Professionel Committees }\end{array}$ \\
\hline
\end{tabular}

STANDARDS AND PROFESSIONAL COMITTEES

Sections

\begin{tabular}{|c|c|}
\hline 3.02 .01 & Purpose \\
\hline 3.02 .02 & Scope \\
\hline 3.02 .03 & Definftions \\
\hline 3.02 .04 & Policy \\
\hline 3.02 .05 & Rocognized Types of Committee Participation \\
\hline 3.02 .06 & Appointment Procedures \\
\hline $\begin{array}{l}3.02 .07 \\
3.02 .08\end{array}$ & $\begin{array}{l}\text { Responsibilities } \\
\text { Approval Procedures for Acceptance of Standards }\end{array}$ \\
\hline 3.02 .09 & $\begin{array}{l}\text { Committee Secretariat Functions } \\
\text { Approval Procedures for Accroditation as a }\end{array}$ \\
\hline & Standardo Developer \\
\hline .02 .1 & Funding \\
\hline & NIST Committee Assignment Recording 0fficers \\
\hline
\end{tabular}

3.02 .01

PURPOSE

This subchapter establishes policies and procedures for the acceptance and maintenance of membership on government and nongovernment standards and professional committees worling in areas related to the activities of the Hational Institute of Standards and Technology. In the case of standards comittees, these policies are consistent with Federal policy guidelines for participation in the development and use of voluntary standards as set out by the Office of Managerent and Budget (OMB) in OMB C1rcular A-119 and Department Administrative Order (DAO) 216-14.

\subsection{2 .02}

SCOPE

a. The policies and procedures in this subchapter apply to employees at NISTGat thersburg and NIST-Boulder.

b. This subchapter covers standards and professionsl committees which ray be national or international in scope.
3.02 .03

DEFINITIOKS

a. Committee - Any board, cominission, councll, conference, penel, task force, or other olnilar group or any subcomittee or other subgroup thereor.

b. Standard - A prescribed set of rules, conditions, or requirewents concerned with the definition of terms; clessification of components; delineation of procedures; specification of dimensions, materials, performance, design, or operations; messurement of quality and quantity in describing meterials, products, systoms, services, or practices; or descriptions of fit and measurement of $812 \theta$.

c. Standards Committee - Any governmental or nongorernmental comititee that exercises polley control over standard activities or that is principelly concerned with the administration of standards programs or the development, approval, or promulgation of standerds. This includes, for example, all committees of the American Society for Testing and Materials (ASTM), as well as 
standards committoes of professional and scientific organisations such as the Institute for Electrical and Flectronics Engineers (IEEE) and the American Nuclear Society (ANS).

d. Professional Committee - Any committee, other than a standards comitteo, which is concerned with the accomplishment of professional, technical, or scientific sobjectives.

e. National Committeo - Any committeo functioning under the furisdiction of a United States orgenization or a Onited States Government agency. Included under this definition are national committees with major international responsibilities, such as the U.S. National Committee for the International Electrotechnical Commission (IEC), and the American National Standards Institute (ANSI) technical advisory groups for committees of the International Organization for Standardiration (ISO).

f. International Committoe - Any committes functioning under the jurisdiction of an international organization (governmental or nongovernmental) such as the International Organization for Standardization (ISO), the International Electrotechnical Commission (IEC), the International Onion of Pure and Applied Chemistry (IUPAC), the International Organiration of Legal Metrology (OMML), and the International Committee of Weights and Messures (CIPM).

\subsection{2 .04}

POLICI

NIST policy encourages and supports perticipation of the professional staff in professional committee activities relating to the scientific and tochnical mission of NIST and in national and international standards committee activities when such perticipetion is in the public interest and is compatible with NIST's mission, suthorities, priorities, and budget resources. NIST employees participating in standards and professional comittee activities relating to the professional besis of their employment carry an inseparable identification with NIST. For this resson, they have fundamental obligation to avoid actions that are inconsistent with established policies and programmatic objectives of NIST, DoC, and the Administration. However, participation In such committees by employees does not, of itself, connote NIST agreement with or endorsement of decisions reached by such groups or of standerds approved and published by voluntary standerds bodies.

\subsection{2 .05}

RECOGMIZED TYPES OF COMITTEE PARTICIPATION a. Approval may be given to an employee to work on standards and professional committee assignments:

(1) By reason of individual professional and technical expertise, or

(2) By reason of management or program responsibilities within NIST, which may justify participation on boards of directors or similar policy-making bodies of stendards or professional organizations.

b. Employees are authorized to serve as full voting members or officers of committees, boards of directors, or similar policy-making bodies of standards and professional organizations unless specifically prohlbited from doing so. However, in order to maintain the private nongovernmental nature of standardsdeveloping organizations, NIST participants on boards of directors or policy-making bodies shall refrain from decision-making involvement in the internal day-to-day management of standards-developing organizations (e.g., selection of salaried officers and employee, establishment of staff salaries and administrative policies).

\subsection{2 .06}

\section{APPOINTMENT PROCEDURES}

The employee is responsible for taking the following actions for each requested committee assignment: 
a. Complete Form NBS-83, Record of Committee Assigmment.

b. Submit Form NBS-83 (original and two copies) to the division chief (or higher official as appropriate) for approval.

Note: Enployees invited to participate on boards or other policy-making bodies of professionel or standards organtzations alist additionally submit Form NBS-83 for -approval to the NIST Director through the Office of the Associate Director for Industry and Standards (ADIS). The request should include the employee's recommendation as to voting or nonvoting status of participation.

c. Following approval, send Form NBS-83 (original and two copies) to Standards Assistance and Kanagement Information, Office of Standards Code and Information (131).

d. Complete and return any forms that may be required by the outside comittee or parent organization.

3.02.07

RESPONSIBILITIES

a. Comittee Participants

(1) Initiate appointment procedures (see Section 3.02.06);

(2) Ensure that Form NBS-83 is up to date for each committee assignment;

(3) Submit committee documents to the NIST Editorial Review Board (Gaithersburg or Boulder) for notation and review, if the documents name an NIST employee as a principal author and the documents are intended for publicetion or distribution outside the comittee. This requirement applies even when the documents will not be issued as NIST publicetions. Inkewlse, submit portions of committee documents that refer to NIST date not previously published to the NIST Editorial Review Boerd. If any special or extensive testing or other experimental work is undertaken for a comittee in NIST laboratories, such work would be considered for summarization in an NIST report or other publication;

(4) Ensure that questionnoires receive required clearance, if any. Questionnaires sent outside the Government by NIST nembers of committees must be cleared by the office of Management and Budget if there are to be 10 or more respondents other than members of the committee or organization in whose nawe the information is being gathered, and 1f:

(a) The name of the Mational

Institute of Standards and Technology appears on the form as a sponsor of the Inquiry; or

(b) NIST is to be the publisher or user of the results of the survey; or

(c) The committee is sponsored by MIST or by another Government agency, even though NIST or the other Federal agency my not be identified on the questionnaire itself.

The Management and Organtzation Division offers assistance and arranges for required clearances.

(5) Ensure that no conflict of interest is involved in their conmittee appointrents; and

(6) Malntain complete records of comittee documents relating to NIST involvement with that comittee, including records of ell NIST participants' votes on committee ballots.

\section{b. Division Chief (or higher official)}

(1) Ensures thet the activity 18 directly related to the authorized functions of NIST and in line with program objectives;

(2) Ensures that the proposed appointee is qualified and can devote enough time and effort to serve creditably; 
(3) Ensures that resources (including funds for trevel and per dien) are avallable or in prospect to oupport necessary participation;

(4) Finsures that the number of individual agency participants in given activity is kept to the inimum required for effoctive presentation of IIST concerns;

(5) Ensures that records of connlttee documents and bellots as prescribed in paragraph 3.02.07a. are malntained within the organizational unit and are readily available for inspection; and

(6) Reviews cosmitteo essignnents periodically to determine if participation is still appropriate.

c. NIST Office of the Associate DIrector for Industry and Standards

(1) Monitors coumlttoe assignnents to ensure thet perticipation of IIST enployees 18 properly authorlzed and consistent with NIST policy as set forth in Soction $3.02 .04 i$ and

(2) Submits annually to KIST center directors a report on staff participation in standards activities.

d. RIST Standardization Advisory and Coordination Committes (SACC)

(1) Advises the NIST DIrector and MOU Directors on NIST-wide issues relating to NIST participetion in standardization activities;

(2) Provides NIST-wide representation in the developent of recomeendations for NIST standards policies and procedures; and

(3) Assists the NIST Director and MOO DIrectors to ensure that RIST standerds participation is effective and efficient. (See Subchapter 3.01 Appendix A for additional resporsibilities and functions of the SACC.)
3.02 .08

APPROVAL PROCEDURES FOR ACCEPTANCE OF STANDARDS COMMITEE SECRETARIAT FUNCTIONS

a. NIST organizational units may assume secretariat responsibilities for national and internetional standerds comittees and their subgroups and may serve as Administrators of U.S. Technical Advisory Groups providing input to internationel standerds committees: However, in accepting such functions, NIST units should not automatically assume final responsibility for ensuring that all approprlate procedures are followed in the stenderds development process, but should seek to persuade the sponsoring perent organization to retain this responsibility. The MOU Director of a designee should effect an agreement within the organization that assumes responsibility for ensuring that all appropriate procedures are followed.

b. If acceptance of the secreteriat is considered necessary to the accomplishment of NIST Object1ves and if no reesoneble sponsor or cosponsor will accept the responsibility for essuring due process procedures, the NIST untt nay take the responsibility upon approval by the KIST Executive Board. Proposals for NIST acceptance of standards comitteo secretariat functions are to bo subuitted through line management to ADIS for pollcy review prior to oubmission to the RIST Bxecutive Board for approval.

3.02 .09

APPROVAL PROCEDURES FOR ACCREDITATION AS A STANDARDS DEVELOPER

RIST organizetional units nay seek accreditation as an American Nationel Standards developer if such accreditation is considered to be essentiel to accomplish NIST objectives. Since ANSI procedures require the standerds developer to provide evidence of conformance to due process requirements, proposels for accreditation of NIST units as Awerican Nationel Standards developers are subject to approval by the NIST Executive Basd. Proposals for accreditation are to be submitted through line management to ADIS for policy review prior to being submitted to the NIST Executive Board for approvel. 
3.02 .10

FUNDING

a. In accordance with 5 U.S.C. 5946, no funds appropriated directly (1.0., STRS) or indirectly (transferred from other agencies) or generated by overhead may be used for the payment of committee membership fees or dues of officers and employees of the Government. However, 5 U.S.C. 4019(b), which authorizes the payment of appropriated and overhead funds toward the necessary expenses of training an employee, also authorizes the payment of individual membership fees, provided that:

(1) The fee is a necessary cost directly related to the training 1toelf; or

(2) Peyment of the fee is a condition precedent to undergoing the training.

b. When an employee perticipates in standards and professionsl committees with NIST approval, the cost of participation is normally paid by NIST. Expenses involved with attondance at meetings are paid by NIST in accordance with DAO 204-1, the DoC Handbook of Travel Policies and Procedures, and the Federal Travel Regulations. If comittee activities are performed by the benefit of another agency, it is appropriate for committee-related travel expenses to be charged to that agency.

c. Comittee memberships and offlcerships in professional organizations which involve use of official time should pertain to research, development, tosting, standardization, symposia, or administrative wark of direct interest to NIST. In order to warrant the charging of time and expenditures to technical cost centers, committeo activities must be closely related to those cost centers.

d. Where the comittee asoigament involves travel costs to be financed by an outside group, the employee wust obtain an NIST travel order that either (1) authorizes acceptance of transportation and accommodations in kind, or (2) 18 charged to the appropriate cost center to which the reimbursement check will be credited. In neither case way the employeo accept monetary reimbursement for travel expenses while in duty atatus since the authority to receive gifts and other reimbursements is limited to NIST as an organization and cannot be extended to an employee. Advice can be obtained from the NIST Comptroller on procedures for accepting funds as payment to NIST.

o. It is usually inappropriate for NIST to take an institutional membership in a private organization. This policy is applicable at all organizetional levels within NIST. Requests for exceptions to this pollcy should be sent to the NIST Director through the Chairperson of the Standardization Advisory and Coordination Committer. Exceptions will be granted only with the epproval of the NIST Executive Board. Soe Subchapter 3.03 for information on approvals required for payment of institutional membership fees to voluntary standards bodies.

Currently approved exceptions are NIST's institutional memberships in the Acoustical Society of America; American National Standards Instituto (ANSI); American Society for Fingineerlng Education (ASEE); American Society for Quality Control (ASQC); American Society for Testing and Materials (ASTM); Association of Blotechnology Companies; BITNET; Computer and Business Equipment Menufacturers Association (CBEMA) $\bar{X}-3$; Corporation for Open Syatems (COS) International; Council for Cherlcal Research; International Councll for Bullding Research Studies and Documentation (CIB); International Institute of Refrigeration (IIR); International Union of Testing and Research Laboratories for Materials and Structures (RILEM); Montgomery County High Technology Counc1l; National Comitteo for Clinical Laboratory Standards (NCCIS); National Conference of Standards Laboratories (NCSL); National Consortium for Graduate Degrees for Minorities in Engineering (GEM); Nationel ROLM Users Group; and Permanent International Committee for Research on the Preservation of Materials in the Karine Environment (COIPM).

3.02 .11

NIST COMMITTEE ASSIGMMENT RECORDING OFFICERS

Standards Assistance and Management Information, Office of Standards Code and Information (131) serves as the NIST Standards and Professional Committeo Monttoring Office. 
APPENDIX C

ADMINISTRATIVE MANUAL SUBCHAPTER 3.03

"PAYMENT OF FEES FOR PRIVATE VOLUNTARY STANDARDS ACTIVITIES" 



\begin{tabular}{|c|c|c|c|}
\hline $\begin{array}{l}\text { U. S. DEPARTMENT OF COMMERCE } \\
\text { NATIONAL INSTITUTE OF STANDARDS AND TECHNOLOGY }\end{array}$ & Chapter & 3 & Committees \\
\hline $\begin{array}{c}\text { ADMINISTRATIVE } \\
\text { MANUAL }\end{array}$ & Subchapter & 3.03 & $\begin{array}{l}\text { Payment of Fees for } \\
\text { Private Voluntary } \\
\text { Standards Activities }\end{array}$ \\
\hline
\end{tabular}

\title{
PAYMENT OF FEES FOR PRIVATE VOLUNTARY STANDARDS ACTIVITIES
}

\section{Sections}

\author{
3.03.01 Purpose \\ 3.03 .02 Scope \\ 3.03.03 Definitions \\ 3.03.04 Policy \\ 3.03.05 Responsibilities \\ 3.03.06 Collection of Fees \\ Appendix A - Standard Language for Administrative \\ Service Fee Contracts \\ Appendix B - Collection of ASTM Fees \\ Appendix C - Collection of ANSI Fees
}

\subsection{3 .01}

PURPOSE

This subchapter states NIST policies and internal procedures for payment of fees in support of NIST participation in private voluntary standards activities.

\subsection{3 .02 \\ $\mathrm{SCOPE}$}

The policies and procedures in this subchapter apply to NIST-Gaithersburg and NIST-Boulder.

\subsection{3 .03}

DEFINITIONS

a. Private Voluntary Standards Bodies Private sector domestic or multinational organizations (such as nonprofit organizations, industry associations, professional and technical societies, institutes, or groups, and recognized test laboratories) that plan, develop, establish, or coordinate voluntary standards.

\section{b. Fees}

(1) Institutional Membership Fees (also referred to as "organizational" or "sustaining" membership feesi - Fees paid for the purpose of obtaining institutional representation in a voluntary standards body. Such fees are intended to be used in support of the organization's general standards-related objectives and programs (i.e., education activities intended to publicize the societal benefits of standardization activities and professional awards programs which provide recognition of individual accomplishments in the field of standardization). An institutional membership usually provides for voting privileges exercised by a representative officially designated by the organization. An NIST institutional membership in a standards body signifies only that NIST endorses the stated purposes of the standards body and that membership is deemed appropriate and necessary in carrying out the mission of NIST. Such membership does not signify that NIST endorses or supports positions taken by the standards body on any subject or issue. An NIST institutional membership in a standards body does not confer individual membership rights or privileges on any member of the NIST staff.

(2) Administrative Service Fees - Fees paid to help cover costs associated with standards committee operation and communication, e.g., preparation and distribution of minutes, circulation of drafts for comment, meeting arrangements, 
and maintenance of committee records. Payment of such fees does not confer individual membership rights or privileges on any member of the NIST staff nor result in NIST being recognized as an institutional member of the standards body.

(3) Individual Membership Fees - Fees paid to standards bodles for the purpose of obtalning membership rights or privileges for individuals.

\subsection{3 .04}

POLICI

a. Federal agencies cannot use direct (1.e., STRS) or indirect appropriated funds (transferred from other agencies) or funds generated by overhead to pay individual membership fees either directly or indirectly (e.g., where purchase of a society journal would confer membership status on an individual) to voluntary standards bod1es (5 U.S.C. 5946).

b. Administrative service fees nay be paid by NIST organizational units if the payment of such fees 18 required by a voluntary standards body in order to serve on a committee(s) of that body and if the MOU Director or designee determines that service on that committee(s) is essential to the achievement of NIST goals and objectives. Contracts, agreements, and letters of intent relating to the payment of these fees must include the language given in Appendix $A$.

c. Payment of institutional membership fees must be approved by the NIST Director.

d. NIST employs a decentralized system for managing the participation of NIST representatives in external standards committee activities (see Subchapter 3.02). Participation 18 monitored by the Office of the Associate Director for Industry and Standards (130). Policy-level questions relating to NIST standards activities are reviewed by the Standardization Advisory and Coordination Committee.

3.03 .05

RESPONSIBILITIES

a. NIST Director - Approves the NIST institutional membership and inftial peyment of fees to private voluntary standards bodies. Requests for approval of NIST institutional memberships and approval to pay institutional membership fees should be sent to the Director through the Chairperson of the NIST Standardization Advisory and Coordination Committee.

b. MOU Directors - Approve peyment of administrative service fees to private voluntary standards bodies.

c. Center Directors - Annuelly revlew lists of staff participetion in standards -activities for appropriateness, indicating changes planned for the next calendar year.

d. Associate Director for Industry and Standards - Maintains information on NIST staff participation in standards committees and activities in conjunction with operation of the NIST Standards Assistance and Management Information project; and provides current lists of NIST participants on standards committees to eppropriate NIST organizational units for verification and roview.

e. Standardization Advisory and Coordination Committee - May select pollcylevel 18sues relating to payment of fees to review or will consider such 1ssues referred by the NIST Director, HOO Directors, or the Executive Board.

\subsection{3 .06}

\section{COILECTION OF FEES}

With the exceptions noted in the appendixes to this subchapter, organizationel units are responsible for paying applicable fees for standards committee activities directly to the organizations concerned after obtaining all required approvals. Copies of all contracts, purchase orders, or other correspondence regarding payment of adrinlstrative service fees or institutional membership fees to stenderds bodies should be sent to the Associate Director for Industry and Standards who maintains records on NIST expenditures related to standards committee activities. 
APPENDIX D

TITLE IV OF THE TRADE AGREEMENTS ACT OF 1979 
ஜ

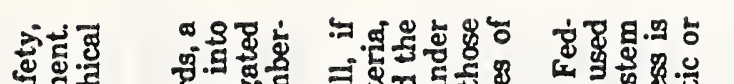

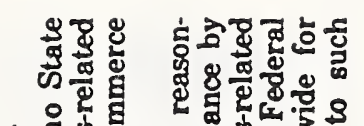

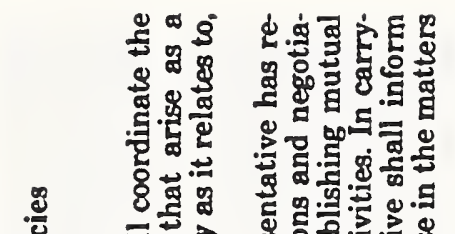

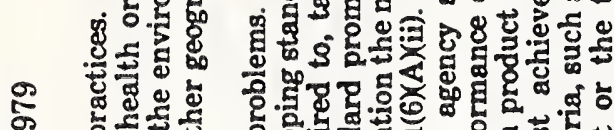

范

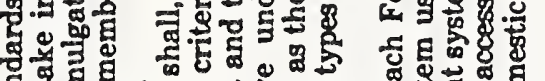

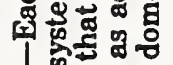

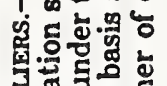

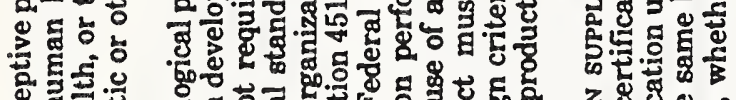

造运

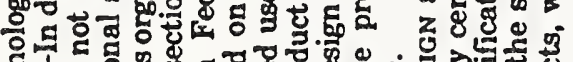

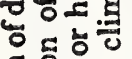

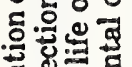

进 $1.9 .0 \%$

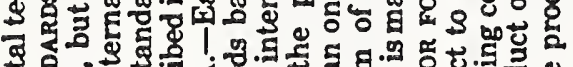

政苍

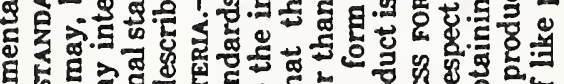

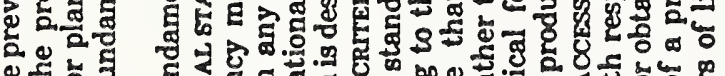

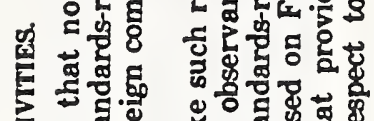

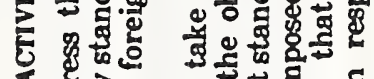

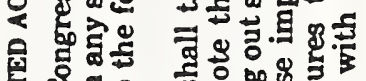

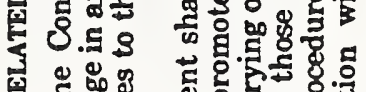

造造

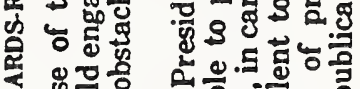

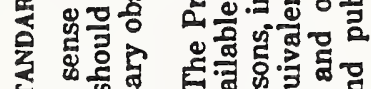

ह

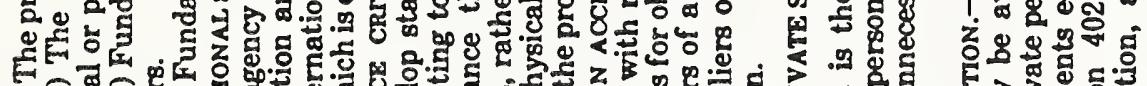

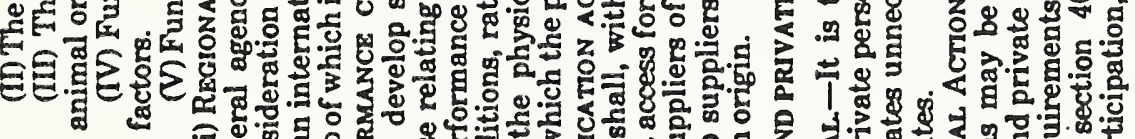

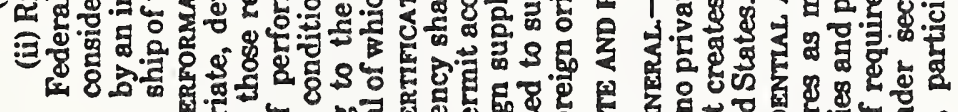

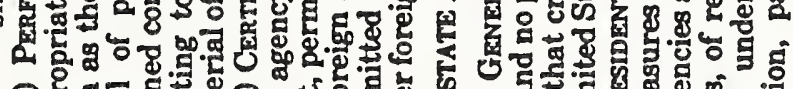

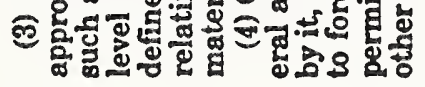

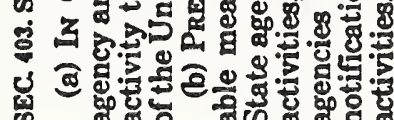

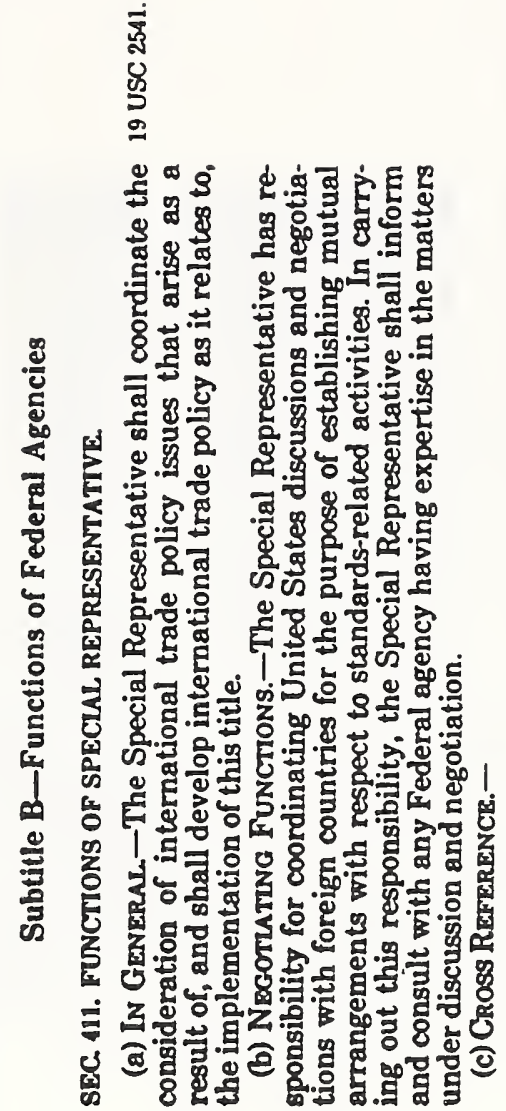

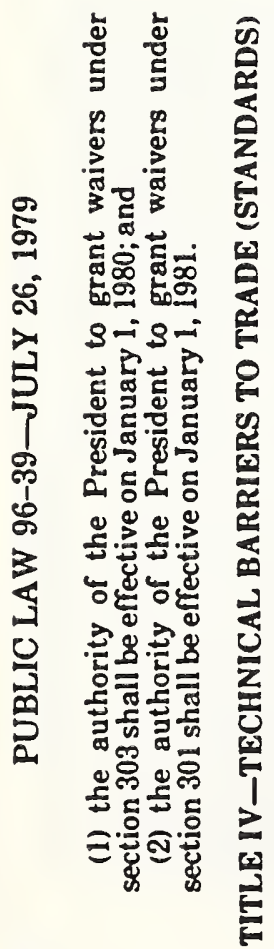

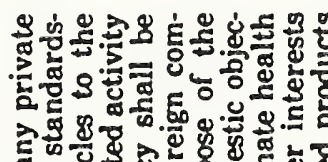

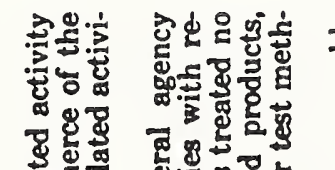

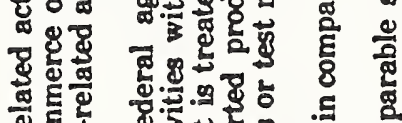

告

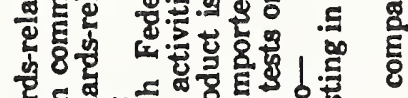

勧.

总

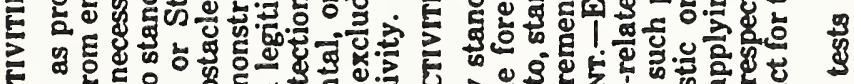

ริ

E

蛋

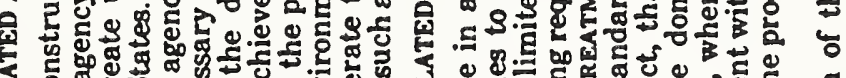

3 o

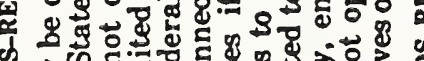

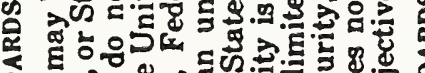

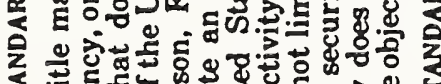

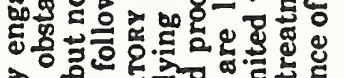

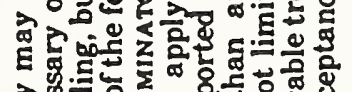

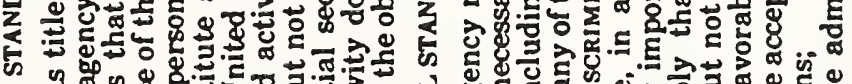

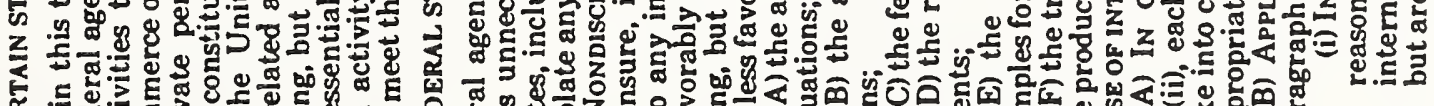

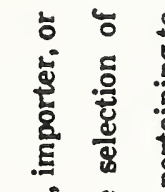

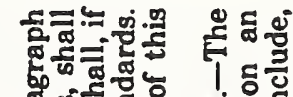

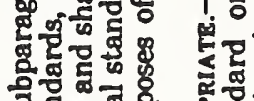

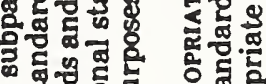

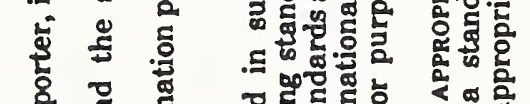

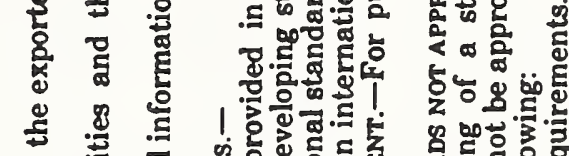

3 苟 可

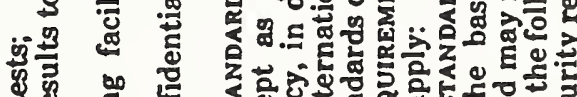

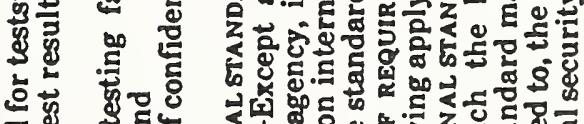

跑

क

o

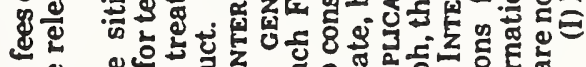

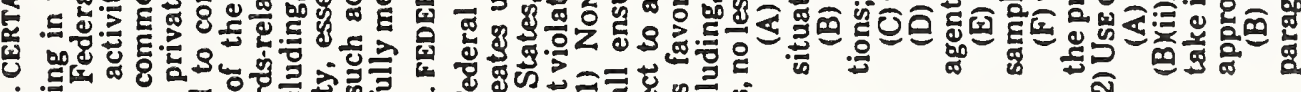

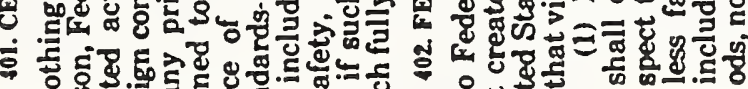

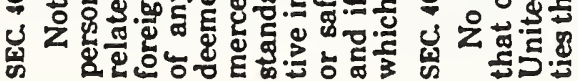

ฟै

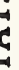


疍
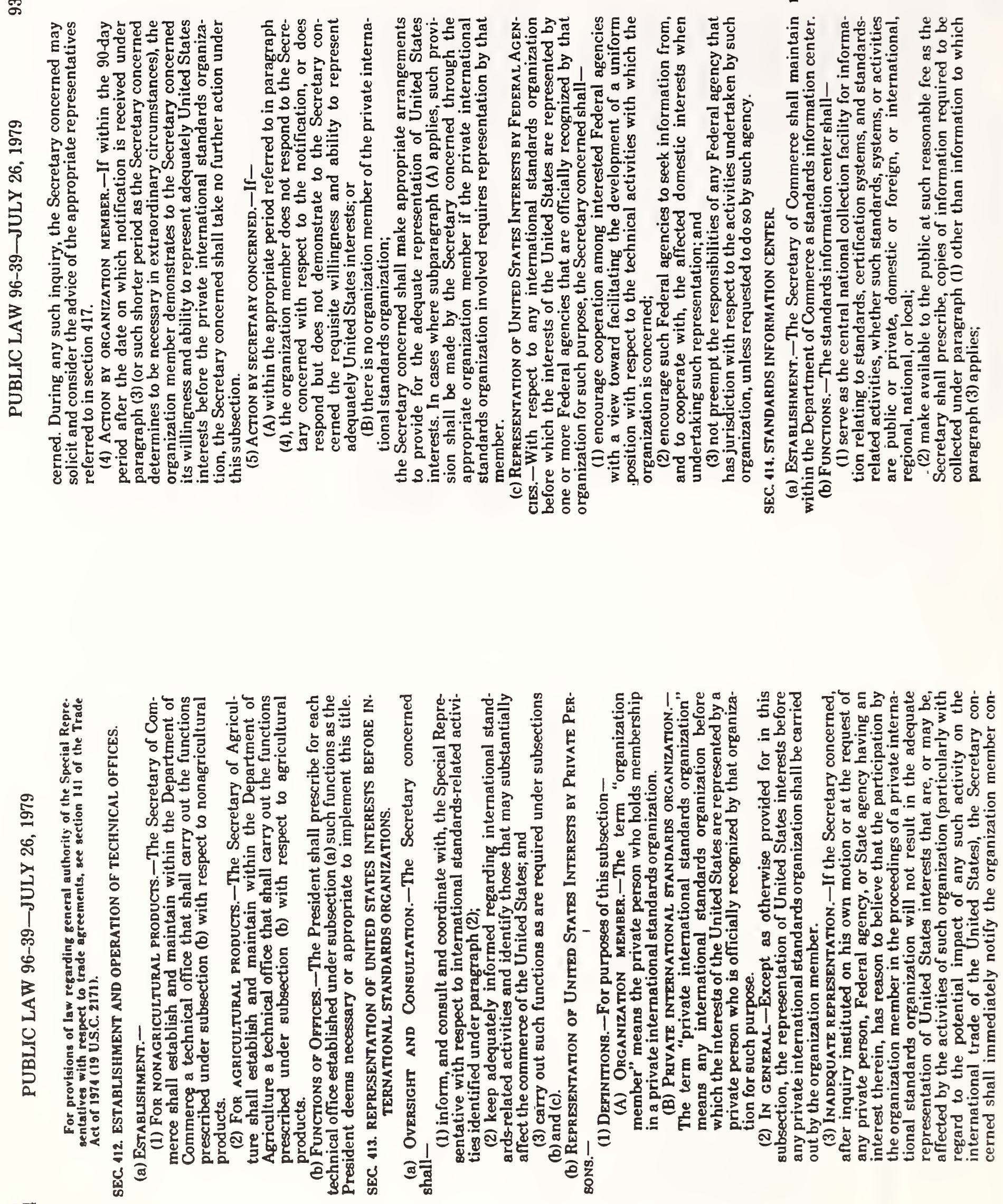

ฟ

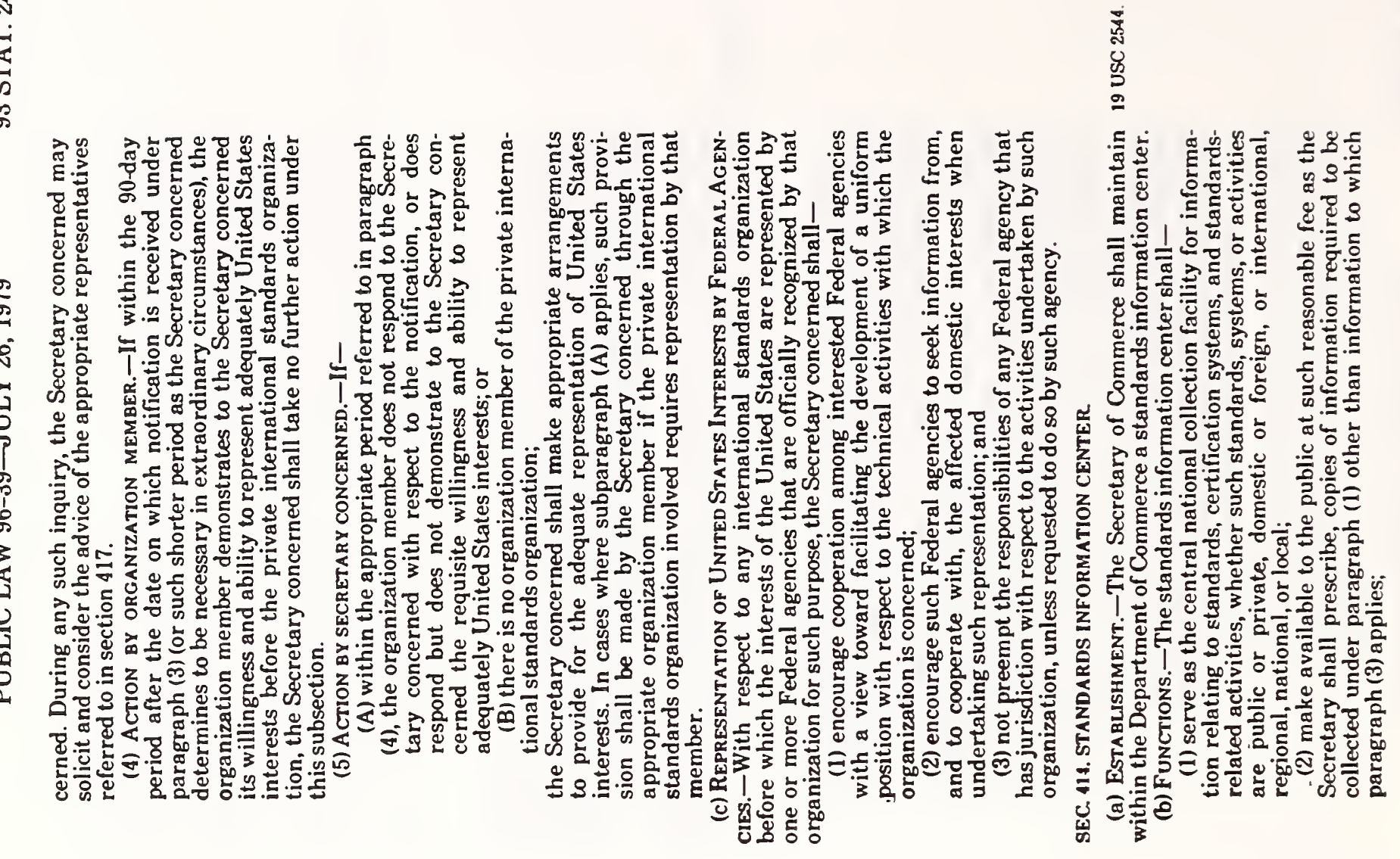




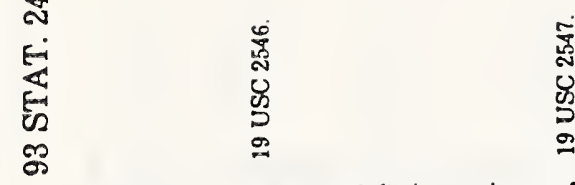

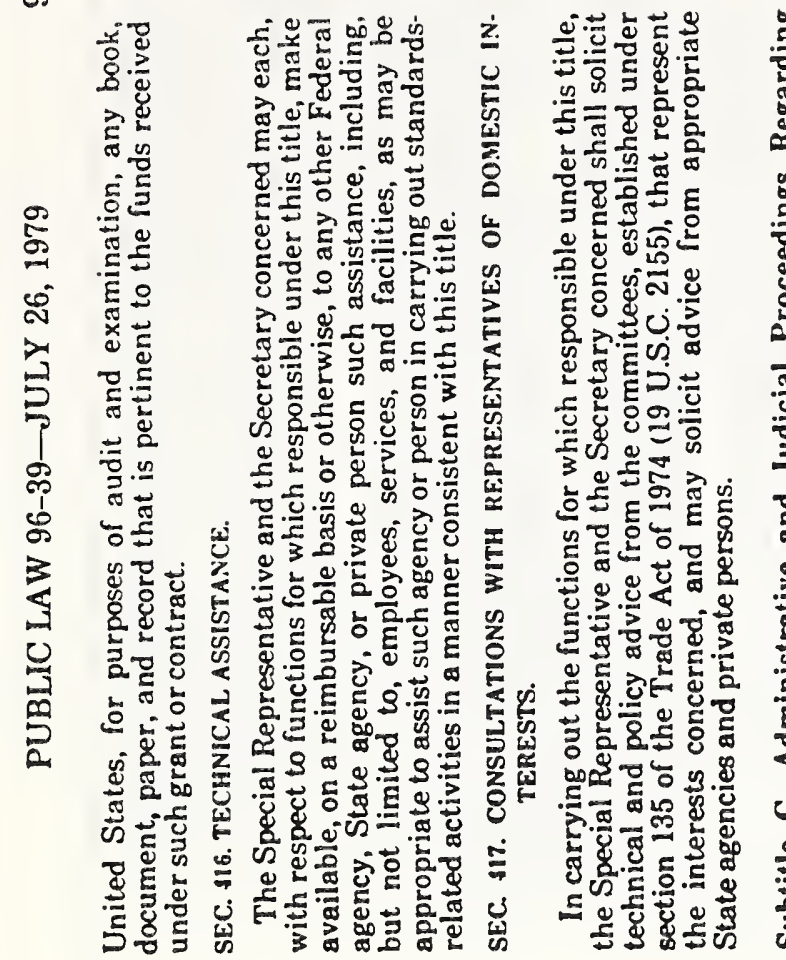

菏薄

然

落落

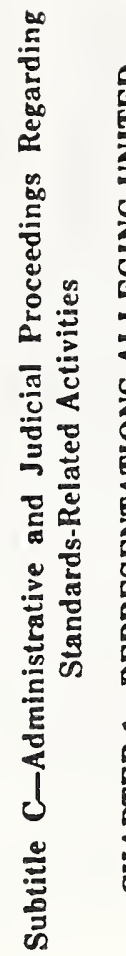

作

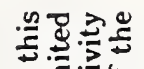

-5.

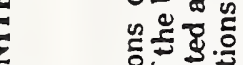

:0

을

욜

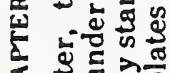

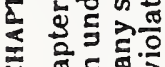

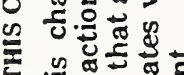

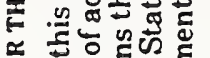

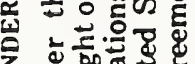

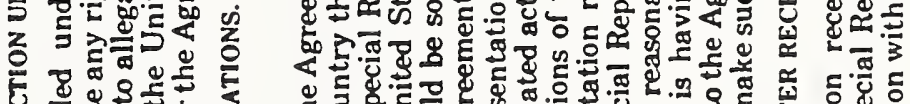

뜨눙

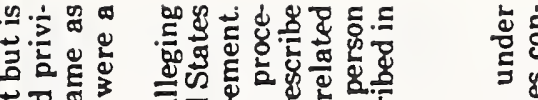

岁

$\begin{array}{ll} & \\ & \end{array}$

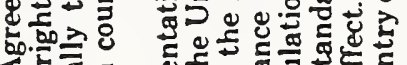

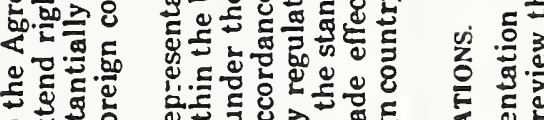

$S$ 的

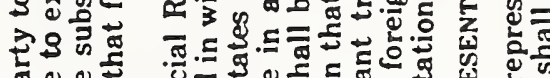

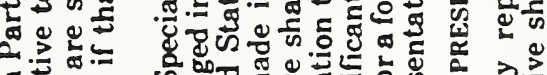

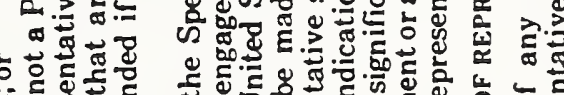

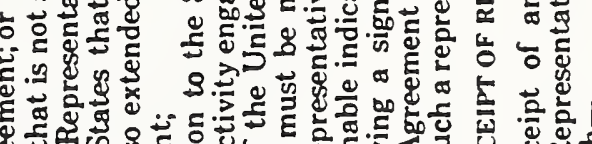
\&

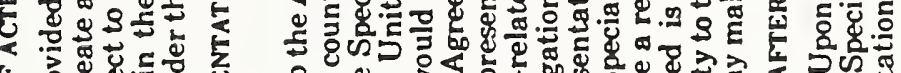

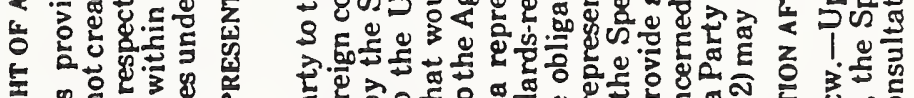

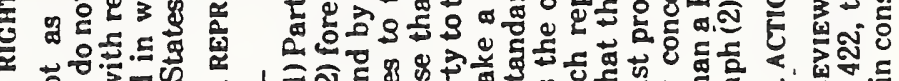

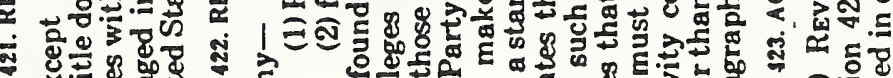
了.

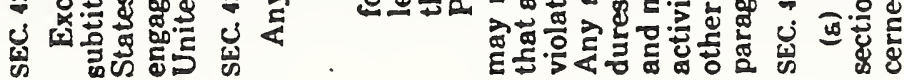

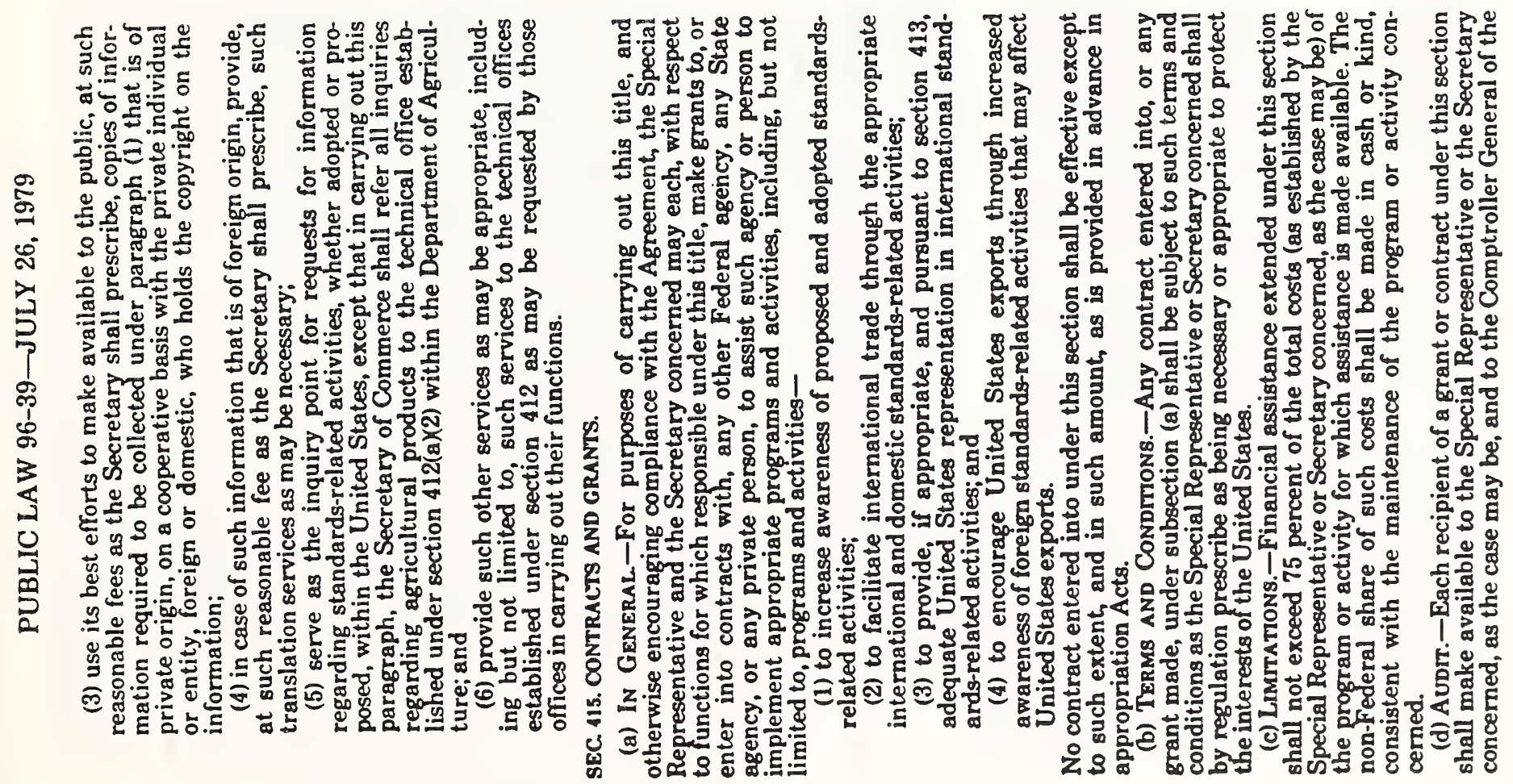




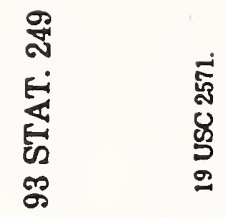

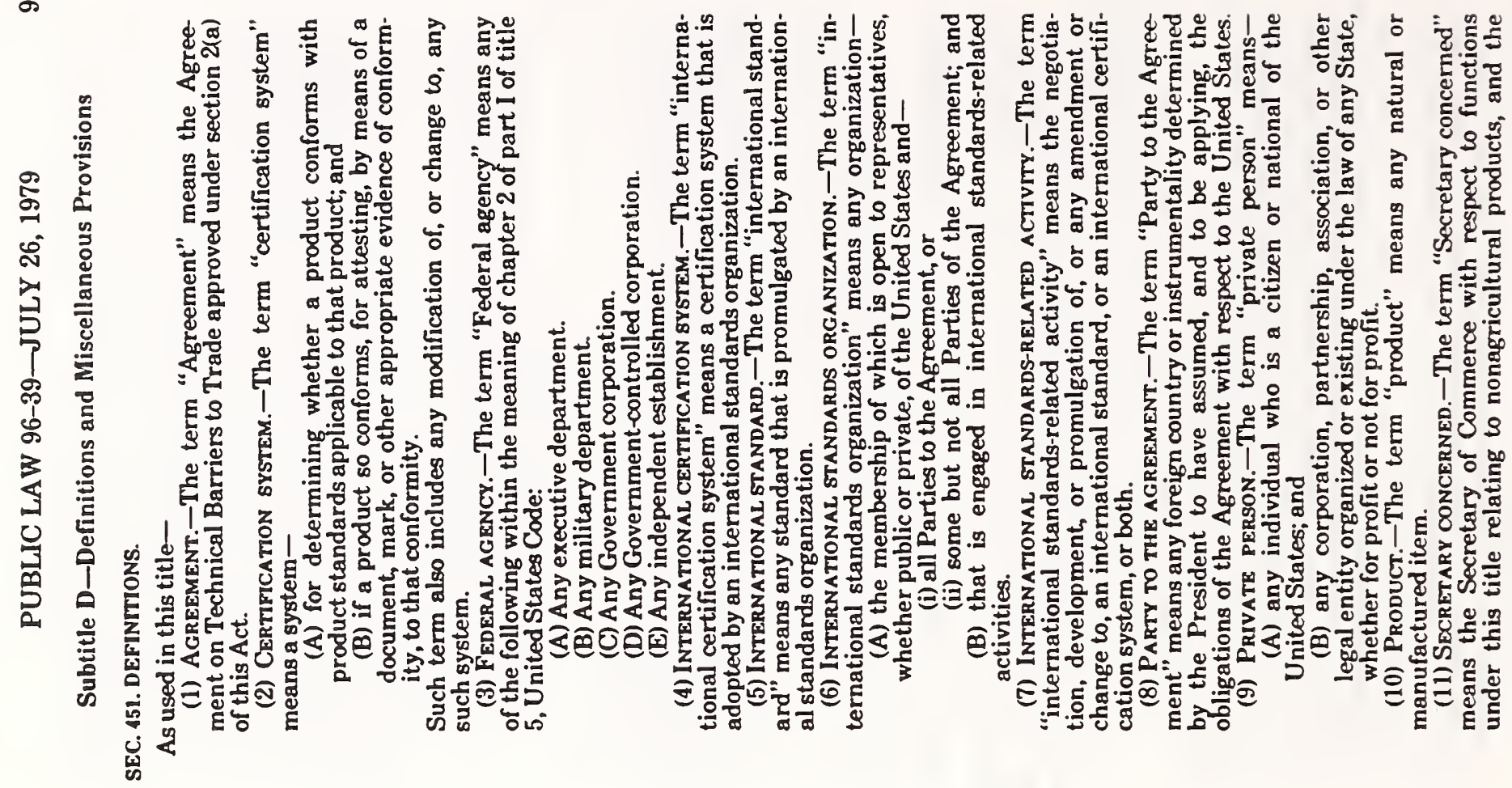

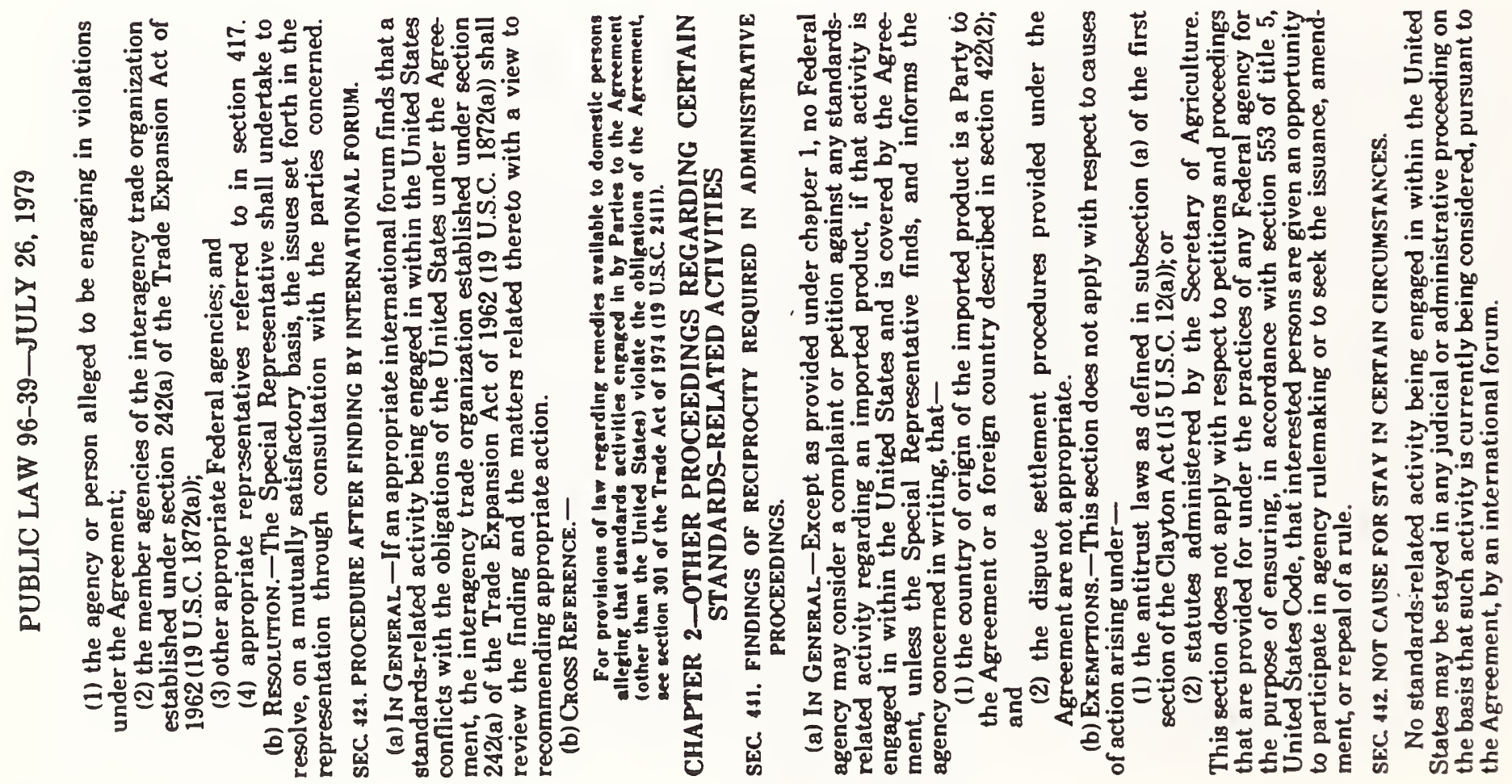

ฟี

E 

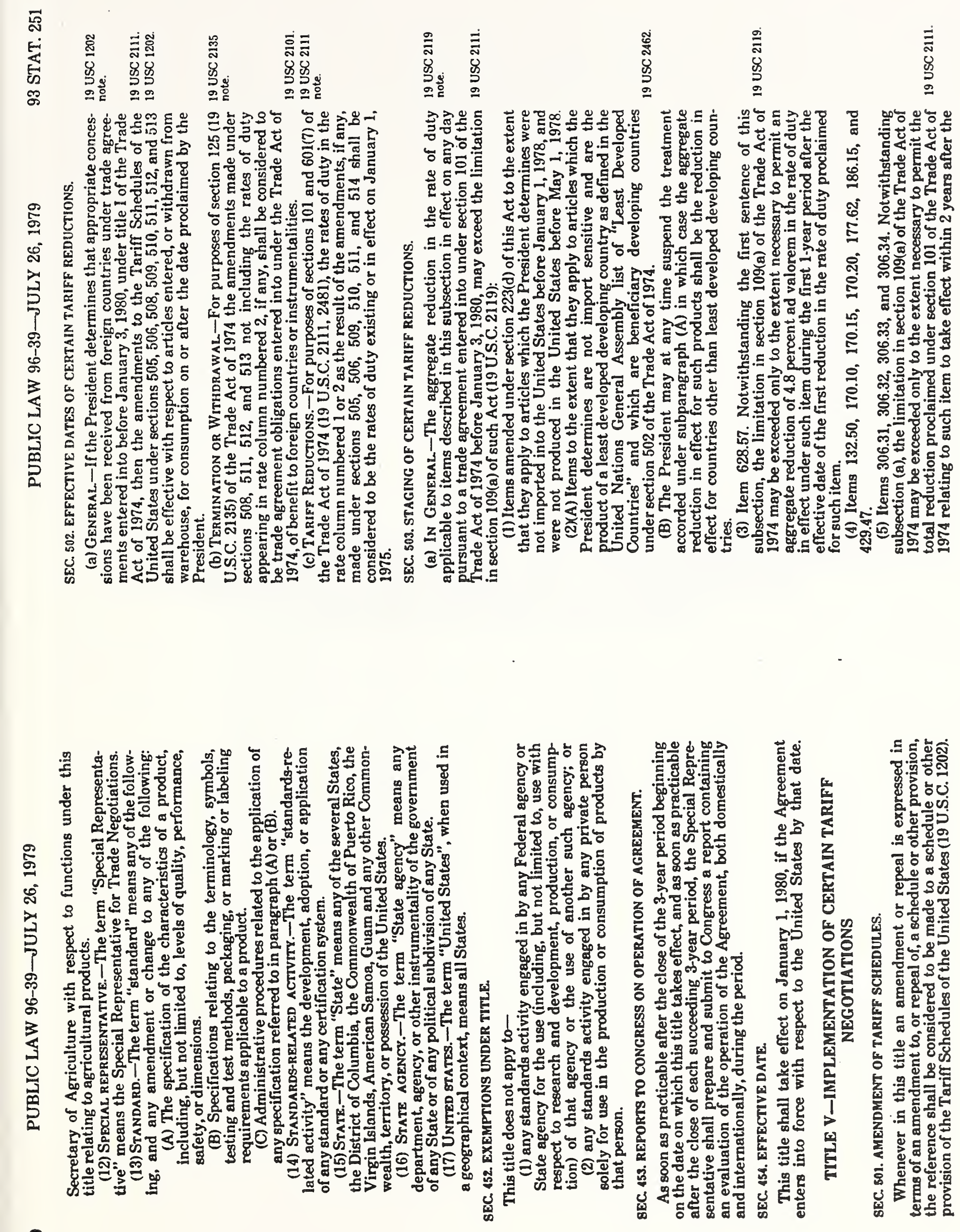

路

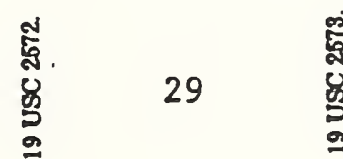

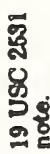


APPENDIX E

FEDERAL REGISTER - FEBRUARY 15, 1984

"GUIDELINES FOR PARTICIPATION BY U.S. GOVERNMENT AGENCIES, EMPLOYEES OR REPRESENTATIVES IN INTERNATIONAL

STANDARDS-RELATED ACTIVITIES" 
Wednesday

February 15, 1984

Notice

\section{National Bureau of Standarde}

Guideline Documents implementing Federal Standards Pollcy

AOEnCr: National Bureau of Standards. Commerce.

ACTrone Notice of Guideline Documents Implementing Federal Standards Policy.

summanr: The purpose of this gotice is to announce the approval by the

Secretary of Commerce of three guideline documents that have been developed by the Interagency Committee on Standards Policy. These documents implement various aspects of the Federal Standards Policy as set out in Office of Management and Budget (OMB) Circular A-119, dated October 26. 1982

The Interagency Committee on Standards Policy (ICSP) was established by the Secretary of Commerce under Section 8.a.(2) of OMB. Circular A-119. The three guidance documents developed by the ICSP are set out in their entirety at the conclusion of this notice.

The first document establishes

"Guidelines for Participation by U.S.

Covernment Agencies, Employees or 
Representatives in International Standards-Related Activities." Section 1 of this document applies to participation in international organizations in which the U.S. Government is the official U.S. member body. Section 2 of this document applies to participation in international organizations in which the U.S. Government is not the official U.S. member body.

The second document establishes "Guidelines for Federal Agency Use of Private Sector Third-Party Certification Programs." The third document provides "Guidelines for Federal Agency Use of Self Certification by Producer or Supplier." These latter two documents are generally applicable to agency procurement and regulatory programs that require statements of conformance to specific standards or specifications.

Comments and questions concerning these guidelines should be directed to Dr. Stanley I. Warshaw. Director, Office of Product Standards Policy. National Bureau of Standards, Washington, D.C. 20234. (301-921-3751). Dr. Warshaw is the Chairman of the Interagency Committee on Standards Policy.

Dated: February 9. 1984

Errest Ambles,

Director. National Bureau of Standards.

Guidelines for Participation by U.S. Government Agencies, Employees, or Representatives in International Standards-Related Activities

\section{Introduction}

The important role that standardsrelated activities have played throughout the whole fabric of national and international economic activities has received increased recognition in recent years. Standards have consolidated and extended the application of technology, helped to conserve scarce resources, improved industrial efficiency, enhanced the general welfare of the public. promoted commerce, and generally improved communication and understanding among the drafters and users of standards. In particular, governments have been giving more attention to the part played by standards as technical barriers to trade. If improperly conducted, international standards activities can suppress free and fair competition, impede innovation and technical progress, exclude safer and less expensive products, or otherwise adversely affect domestic and international commerce.

The role and functions of U.S.

Government agencies, employees, and representatives in international standards-related activities have not been clearly defined. Consequently, the interpretation of that role has varied among Federal agencies, the private sector, and foreign countries. Other factors have also prompted the need to establish uniform Federal guidelines in the international standards area, notablyD

1. The increasing tendency of governments to regulate or procure by "reference to standards":

2. The growing impact of national standards upon domestic and international commerce;

3. Current international activity aimed at preventing barriers to trade that arise from differing national mandatory and voluntary standards, including heightened interest in the development of international standards and their subsequent national adoption; and

4. An expressed desire by several U.S. Government agencies for such guidelines.

A recent U.S. development covering the subject of standardization gives further impetus for the development of guidelines covering Federal participation in international standardization activities:

- Trade Agreements Act of 1979. Title IV-Technical Barriers to Trade (Standards), effective January 1.1980. Section $\mathbf{4 1 3}$ of that Act deals specifically with representation of U.S. interests before international standards organizations. Regarding private international organizations, this section recognizes the role of U.S. private sector members of such organizations and grants the Secretaries of Commerce and Agriculture authority, under certain circumstances, to provide for adequate U.S. representation in those private international standards organizations through the U.S. member bodies. Regarding representation of U.S. interests by Federal agencies, Section 413(c) encourages cooperation among Federal agencies regarding the development of uniform positions, and encourages such Federal agencies to seek information from and to cooperate with domestic U.S. interests. Paragraph 2.3 of the international Standards Agreement itself calls upon parties (e.g., the U.S. Government) to "play a full part within the limits of their resources in the preparation by appropriate international standardizing bodies of international standards for products for which they have either adopted, or expect to adopt. technical regulations or standards."

The recent and rapid expansion of international cooperation in trade and defense emphasizes the need for effective government involvement in the development of acceptable international standards (including test methods and certification) and requires that the limited U.S. Government resources contributing to such standards be expended effectively through efficient Government representation in and coordination with international standards organizations. These guidelines provide direction for strengthening such efficiency and effectiveness. Accordingly, the aim of this document is to provide guidance to U.S. Government agencies, employees, and representatives who participate in:

(a) International organizations in which the U.S. Government is the official U.S. member body (commonly called intergovernmental organizations), e.g.. International Organization of Le.gal Metrology (OLML).

(b) International organizations in which the U.S. Govermment is not the official U.S. member body and where the United States is represented by a domestic private sector organization that is recognized by a private international organization as the U.S. member body, e.g.. International Organization for Standardization (ISO) and International Electrotechnical Commission (IEC), where the U.S. member body is the American National Standards Institute (ANSI).

Although the two types of organizations are treated separately in these guidelines, such guidelines are uniform by being applicable to both types to the maximum extent possible.

These guidelines cover not only Federal participation in international conferences and meetings, but also participation in the development of U.S. positions in preparation for these conferences and meetings.

The application of these guidelines will vary from time to time and from committee to committee according to the end-use of a standard. Much will depend on whether the international standard under development is to be considered for reference in regulations and. if 80 , whether compliance with its provisions is likely to be mandatory. and whether there are relevant existing or proposed national or international requirements. These and similar considerations will influence the role of the U.S. Government representatives participating in standards-developing groups. This document is intended to help such representatives discharge their responsibilities while promoting the development of reasonable and effective international standards. 
It should be noted that individual U.S. Government departments may, in order to cover special interests, issue supplementary instructions to their representatives. Where possible, these instructions should be compatible with the principles contained in these guidelines. Attached to these guidelines is a list of Federal agency contact points on international standardization.

\section{Glossary}

Accredited-Official authorization to serve as a member of a delegation to an international standards-related activity.

Delegation-Representatives of a nation or member-body empowered to act at an international standards-related meeting.

Delegate-An accredited member of a delegation.

Head of Delegation-The person responsible for guiding the delegation at the international meeting and presenting the U.S. position.

Representative - An individual designated by a Federal agency as its official participant in international standards-related activities and/or development of U.S. positions thereon.

Principal Representalive-The Federal representative designated to act as the primary U.S. Government spokesperson and coordinator when two or more Federal agencies participate in an international standards-related activity. The principal representative may function also as head of the delegation.

International Standards or Standards. Related Activities or OrganizationsIncludes standards, testing, and certification.

Lead Agency - A Federal agency which assumes responsibility for effective U.S. Federal representation in the International standards-related matter concerned.

Technical Offices

\section{Deportment of Commerce}

Technical Office for Implementation of Title IV of Trade Agreements Act/ 1979: Office of Product Standards Policy. National Bureau of Standards, U.S.

Department of Commerce. Washington. D.C. 20234.

\section{Department of Agriculture}

Technical Office, Trade Relations Division, International Trade Policy, Foreign Agricultural Service, U.S. Department of Agriculture. South Agriculture Building. Washington. D.C. 20250.
Section I-Guidelioes for Participation by U.S. Government Agencies, Employees, or Representatives in International Standard-Related Organizations in Which the U.S. Government is the Official U.S. Member Body

Subsection A. Delegation Accredited by U.S. Department of State

1. Scope. Subsection A applies only to international conferences, which are defined as meetings of three or more governments whose representatives are formally accredited by their governments to the sponsoring international organizations or host government. When this is the case, the U.S. delegation represents the U.S. Government as a whole. Such meetings may result in a formal commitment(8) by the U.S. Government of a policy nature. Subsection A does not apply to bilateral discussions or meetings of subsidiary international bodies which are intended to produce only recommendations to a higher authority of the organization concerned, and whose subject-matter is predominantly technical (in c ontrast to policy). The final arbiter as to whether or not a particular meeting meets the definition of an international conference (i.e., whether it falls under Subsection A or Subsection B) rests with the Office of International Conferences, U.S.

Department of State.

2. Lead Agency. The U.S. Federal agency having primary responsibility or authority for the subject matter of the meeting normally is designated by the Department of State as lead agency. In cases where such primacy is not clear or is in dispute, the Department of State determines the lead agency. The lead agency should assume responsibility for U.S. preparations to the conference. assure that nominations for the delegation reach the Office of International Conferences in a timely fashion, and take responsibility for the effective representation of U.S. interests in the matter concerned.

3. Nomination and Accreditation of Delegation. The delegation should be proposed to the Office of International Conferences (OIC), U.S. Department of State by the lead agency or by an Interagency committee headed by the lead agency. The Office (OIC) recognizes that particularly in standards matters and effective representation therein, experience and continuity of participation are important considerations in the composition of delegations. Each person proposed for delegation membership including the U.S. representative (head of delegation), alternate, government advisors, and private sector advisorf, as appropriate. will be justified on the basis of his or her essentiality to the work of the delegation. Because the delegation will represent the United States Government as a whole and will be instructed on U.S. positions on all major points, each interested agency need not have a representative on the delegation. OIC exercises delegated Presidential authority in accrediting U.S. delegations. Final decisions on the size and make-up of delegations including the resolution of any interagency differences thereon will be made by OIC.

4. Development of U.S. Positions. It is the responsibility of the lead agency to insure that a position paper is drafted on each relevant agenda item and that these papers are properly coordinated and cleared. In the discretion of the lead agency, U.S. positions may also be drafted on points which do not appear on the official agenda.

5. Coordination Outside of Government. The lead agency should seek the advice of person and organizations outside the U.S. Government whose interests may be materially affected by the subject-matter of the conference, especially U.S. trade interests. Such advice should be solicited in writing or through meetings prior to the development of the U.S. position.

6. Intra-government Coordination. It is the responsibility of the lead agency to insure that all interested government departments and agencies have the opportunity to review proposed U.S. positions and to resolve any differences which may occur prior to the international conference. It is the responsibility of the head of the delegation to insure that all members of the delegation are fully acquainted with the U.S. position and that they maintain necessary conformity therewith regardless of differences which may have existed previously.

7. Report of Delegation. The head of the delegation is responsible for preparing and submitting to OIC a final report on the meeting in accordance with instructions from OIC. That report should be made available by the head of the delegation to all members of the delegation and, if unclassified, to any interested party. Wherever possible. reports should be unclassified. Where security classification is necessary, only that portion of the report which merits classification should be 80 classified and indicated as such (see Executive Order 12356). When international trade is involved, the head of the delegation should transmit a copy of the report promptly to appropriate agencies and organizations, including the Department 
of Commerce's Technical Office for implementation of Title IV of the Trade Agreements Act of 1979 on matters relating to non-agriculture products, and to the Department of Agriculture's Technical Office for implementation of Title IV on matters concerning agricultural products. Recommended contents of the report are:

a. Results of meeting in terms of U.S. objectives, including issues which were discussed but which did not appear on the agenda, if any:

b. Matters for further U.S. action or consideration, especially significant problem areas which may affect U.S. trade:

c. Information on future meeting(s), if available; and

d. Implications, if any, for U.S. export prospects and for competition in domestic markets.

\section{Subsection B. Delegations Not}

Accredited by U.S. Departmert of State

1. Scope. These guidelines apply to all participation by U.S. delegations in standards-related meetings of international organizations in which the U.S. Government is the official U.S. member body, except those in which the U.S. Department of State accredits the U.S. delegation, in which case Subsection A shall apply.

2. Lead Agency. The Federal agency havino primary responsibility for U.S. participation in the internationa! organization under whose auspices the meeting is to be held is responsible for assuring adequate U.S. participation at the meeting. In the case of planned meetings (e.g., topical conferences. symposia) which are not under the auspices of a single international organization, the U.S. Government agencies having interests in the subject matter should cooperate in deciding which will act as lead agency. The lead agency should inform the relevant

"Technical Office" of the Department of Commerce or Agriculture, as appropriate, of standards meetings whose outcome may affect U.S. trade.

3. Meeting Preparations. The lead agency is responsible for coordinating the many details involved in preparing for U.S. participation in international standards-related meetings. It is incumbent on the lead agency to take all reasonable steps to: assure adequate funding of the U.S. delegation; obtain necessary clearances (travel or otherwise); and. instruct the delegation in its responsibilities and duties.

3.1 Formation of Delegation. The lead agency is normally responsible for formation of the delegation and for the specific assignments of work to the delegation. In carrying out these responsibilities the following points should be taken into consideration:

3.1.1 Size of Delegation. The lead agency should use sufficiently selective criteria to ensure that the size of the delegation is justifiable in terms of the importance of the meeting to U.S. national interests.

3.1.2 Balanced Representation. The composition of the delegation requires careful consideration and planning. In selecting the delegation, the lead agency should take into consideration: The nature and purpose of the meeting; the possible impact of the meeting's results: the use of qualified women and minorities; and, the interests of all parties that may be substantially affected within the United States. In those cases where the meeting may result in technical requirements or standards which may measurably affect trade, or which may be adopted as law or regulation within the United States, it is particularly important to seek representation on the delegation from the affected community (e.g., industry, other Federal agencies, State and local governments, labor, universities. consuming public). The lead agency may find that, while there is interest in participation in the delegation by such groups, they may lack the necessary funds to do 80 (particularly to pay for international travel). In such cases a balanced U.S. viewpoint can often still be achleved by having all interested parties participate in preparatory meetings held to review, comment on. and agree on positions to be taken by the delegation during the international meeting.

3.1.3 Head of Delegation. In making its selection the lead agency should appoint as head of delegation an able negotiator who is: Experienced in the subject matter of the meeting; familiar with the policies and procedures of the international organization sponsoring the meeting; and. capable of maintaining harmony within the delegation.

3.1.4 Accreditation of Delegation. Once the composition of the U.S delegation has been decided, the lead agency is responsible for satisfying any requirements imposed by the relevant international oryanization as regards accrediting or advanced notice of delegations. Generally, sponsors of international intergovernmental meetings request advance notification of participation. Every effort should be made by the lead agency to respect such requests in a timely fashion. Often, a simple letter of appointment to each delegate serves many useful purposes even when not required. For example, a letter of appointment is often useful in justifying participation in a standards meeting to higher management.

3.1.5 Continuity of Delegation. In recognizing that the effectiveness of a delegation is enhanced by the long-term continuity of participation by particular delegates, the lead agency should endeavor to provide and maintain that continuity.

\subsection{Preparation of Position Papers.}

While it is advantageous to prepare position papers in advance of the mesting, there are many instances when advanced preparation of position papers is not practical because of the technical nature of the meeting, insufficient information as to the exact agenda to be discussed, or insufficient time. Consideration should be given to the nature, purpose, and status of the meeting in determining the need for position papers. For example, there are many meetings of a technical nature where delegates participate as experts under the rules of the organization and are free to take positions without committing their governments to a particular course of action. Delegates to such meetings should be prepared to take positions which have been coordinated with appropriate U.S. interests, although it may not have been possible to prepare position papers concerning the points involved. Further. technical discussions, particularly in the early stages of standards development. are free-wheeling and delegations should have the latitude to freely debate technical issues. In the standardization process, there are normally a number of iterations of a draft standard as it moves through the system. Position papers may, therefore, be more appropriate in guiding the delegation in later stages of standards development when delegations are expected to vote on adoption of the standard. It is sometimes also useful to prepare position papers for items not on the official meeting agenda but which are deemed likely to arise or otherwise be relevant to U.S. interests. In any case, the lead agency and the head of delegation should determine whether position papers are appropriate. When they are, the following guldelines should be followed.

3.2.1 Unresolved Issues. The head of delegation, with assistance as appropriate from the lead agency. should be responsible for the preparation of position papers. If agreement on a U.S. position on all major issues cannot be reached, the head of delegation should elevate any unresolved issue to the lead agency for resolution. in consultation with affected 
interests (other agencies, private sector. etc.) where possible and practical.

3.2.2 Clearance of Position Papers.

The head of delegation in cooperation with the lead agency should determine on a case-by-case basis what clearances of position papers, if any, are appropriate. With lead agency assistance, the head of delegation should also be responsible for obtaining such clearances.

3.3 Coordination With Affected Interests. Ensuring that affected U.S. interests have been taken into account in the preparation for the international meeting is perhaps the most difficult and yet most important responsibility of the lead agency and head of delegation. For obvious reasons of time and resources. there must be limits to the effort of coordinating positions. Accordingly, the lead agency and head of delegation should decide what actions need to be taken. If the meeting involves the development of technical standards which may become that basis for the conduct of international trade or of law or regulation in this country or in other countries, U.S. interests which may be materially affected by these standards should be notified of the meeting and provided with relevant information and the opportunity to comment on proposed positions. This may be accomplished in any feasible manner, including the solicitation of written comments or a meeting. The lead agency and head of delegation should be particularly aware of international standards activities which may overlap or duplicate ongoing activities either in other international organizations (intergovernmental or voluntary) in which the U.S. is a member, or within U.S. standards bodies, and should wherever possible take steps to reduce the possibility of duplication of effort.

3.4 Prevention of Trade Barriers. Government agencies and employees should be mindful that a standard may. if improperly written, create an unnecessary barrier to trade. Likewise, they should also be aware that some standards may be written in such a way as to impede innovation and technological progress and should strive to provide standards that promote innovative processes and technological advances when they are in the public interest. In general, standards based on performance criteria are less likely to pose competitive concerns than desiga. material, or construction criteria.

Accordingly, preference should be given to performance criterion whenever they roasonably may be used in lieu of design, material, or construction criterion.
3.4.1 While a standard may include a product incorporating a device or process which is patented, it is undesirable for a standard to be written in such a way as to require the use of the patented device or process in order to be in conformance with the standard. Normally this problem can be avoided by writing standards based on performance criteria rather than design, materials, or construction criteria. There may be occasions, however, where there is a great need for a particular standard to be written to specify a patented iter. Most standards organizations have patent policies which require that if an item which is patented is included in a standard, the owner of a patent must declare that the patent is available for unsestricted licensing under reasonable terms and conditions. Govermment participants should familiarize themselves with the patent policies of the organizations in which they are participating, and discuss them with their agency counsel should there be any questions.

3.5. Technical Quality of Standards. It is particularly important that a standard under development is technically sound, within the operating scope of the organization and meets defined needs of the member nations. This may require that the Govermment representative consult with other Government experts or with persons in other organizations who are not directly involved with the standard under consideration. Where a standard does not meet a particular set of needs or is not technically sound in the view of the Government participant, he/she should work with the committee to make the necessary corrections. If unsuccessful, the participant should oppose the adoption of the standard and report such action to agency management.

4. Meeting Participation. To be effective at international standards. related meetings, a U.S. delegation has to be prepared not only for the substance of the meeting, but also for possible side issues and actions that can have a significant impact on the success of the delegation. Instructions to a delegation include information on how to cope with unforeseen matters or with extraneous political issues that might arise during the meeting, and should stress the importance of team work and the need for the delegation to be constantly aware that their actions, in and outside of the meeting, should reflect credit upon the United States.

4.1 Responsibilities of the Delegation. Delegates shall at all times maintain the highest standards of personal and professional conduct.
4.1.1 Head of Delegation. The head of delegation is responsible for guiding the delegation and for presenting the U.S. position, taking into account the guidelines contained in 4.1.3.

4.1.2. Delegation Members. Members should assist the head of delegation wherever possible to ensure the success of U.S. participation in the meeting and should accept such responsibilities as are assigned, taking into account the guidelines contained in 4.1.3.

4.1.3 Participation Guidelines. Delegates to standards meetings represent the public interest of the United States. Serving the public interest requires a consideration of the viewpoints and objectives of all affected parties and the choice of alternatives which promise to yield the greatest economic and societal benefits to the United States. Participation should be guided by the following points.

4.1.3.1 Unforeseen Matters. At the discretion of the head of delegation. unforeseen matters which arise during the meeting should be addressed by the delegation. If the delegation cannot agree on a position on-the-spot, the head of delegation should either seek time to obtain instructions from the lead agency, or abstain from expressing a U.S. point of view.

4.1.3.2 Unauthorized Personnel. Only persons named as members of the delegation should participate in the work of the delegation. There may be instances when qualified American citizens are at the site of the meeting. and the head of delegation may wish to consult them on technical matters. Such consultation is permissible, but the persons may not be accredited or speak as members of the U.S. delegation without expressed prior authority from the lead agency.

4.1.3.3 Press/Media Relations. The head of delegation is responsible for any press, media, or public statements of the delegation. Except as specifically instructed to the contrary, the head of delegation is under no obligation to make any public statements regarding the meeting or on actions or positions taken by the delegation during the meeting. Public statements to the press/ media should be made only after careful deliberation, keeping the general interests of the United States in mind. Where possible, the head of delegation may wish to consult with Embassy. Consulate, or appropriate Mission officials before making public statements.

4.1.3.4 Meetings in the United States. Arrangements for hosting an intemational meeting in the United States are likely to require a very long 
lead time and may involve considerable expense. The head of delegation should neither invite a meeting of any kind to the United States nor imply that the United States would be willing to host a specific meeting without prior approval as appropriate.

4.1.3.5 Extraneous Political Issues. It is the policy of the United States Government that at standards-related meetings or at conferences of a technical, professional, scientific, or other specialized nature, it is inappropriate to inject extraneous political subjects. Accordingly, the U.S. delegation may not initiate political discussions and should oppose on a point of order the injection of political matters into the meeting by other delegations.

4.1.3.6 Commitments of U.S. Participation in International Activities. At the meeting, careful consideration should be given to any possible commitments that may entail significant expenditures of U.S. resources. This applies in particular to: participation of U.S. persons on committees, working groups. etc., other than for the duration of the meeting; undertaking Secretariat duties or committee chairmanships; and hosting of meetings in the United States. The U.S. delegation should make tentative commitments only when necessary. In such cases, care should be taken to ensure that the commitments being made are clearly understood as tentative pending official confirmation.

4.1.3.7 Expression of Personal

Opinion. Delegates should refrain from publicly or privately expressing opinions on U.S. policies or programs not germane to the meeting. When personal opinions, germane to the meeting are expressed, they should be clearly identified as personal and unofficial.

4.1.3.8 Presentation of U.S. Positions. As stated in 4.1.1, the head of delegation is responsible for presenting the U.S. position during the meeting. During the meeting, members of the U.S. delegation should not speak on behalf of the delegation without the approval of the head of delegation.

4.2 Voting Guidelines. During certain international standards meetings, entire standards are approved by ballot and the U.S. delegation will be expected to vote on adoption of a standard(8). The procedures of international standards bodies generally require approval of draft international standards at a number of successive levels (e.g.. at the subcommittee, committee, and final or plenary level) before final adoption. The following guidelines for establishing U.S. positions on approval of draft standards are intended as a step towards a unified Federal Government approach to the development and use of international standards.

4.2.1 Voting "Yes" to Approve Draft Standards. Subject to the guidelines concerning trade barriers in section 3.4, consider voting "Yes" to approve an entire draft standard under any one of the following circumstances:

(a) If there is a U.S. national standard (a standard generally accepted within the U.S.), or a relevant regulation, or Federal agency policy which can be considered to be equivalent to the international document under consideration.

(b) If any conflict between the international document and U.S. practice (standard, regulation or policy) is such that the U.S. practice could be modified to conform without losing equivalence. In such cases the affirmative vote should bs accompanied by a statement that, "the U.S. affirmative vote recognized the following minor technical additions, or changes, which may be included in the national standard, regulation or policy."

(c) If no relevant U.S. standard, regulation or policy exists and the international document is technically acceptable and could be used to develop national standards.

4.2.2 Voting "No" to Disapprove Draft Standards. Consider voting "No" to not approve an entire draft standard under any one of the following circumstances:

(a) If the international document is considered to be not equivalent to or in clear conflict with a U.S. national standard, regulation of Federal agency policy.

(b) The international document is not technically acceptable.

(c) If a U.S. standard, regulation or policy exists which differs from the international document only because the national practice (standard, regulation or policy) includes additional or more stringent requirements. In such a case, the U.S. Vote should be accompanied by comments pointing out that additional requirements must be met to satisfy the national practice.

(d) The international document unnecessarily creates a barrier to domestic or international trade, or impedes innovation or technological progress.

Reasons must be given for a negative vote. The U.S. vote must, therefore, be accompanied by reasons for the negative vote, such as exceptions and/ or additions that will be required to conform with our safety practices or regulations.

4.2.3 Voting to "Abstain" on Draft Slandards. Consider "Abstanining" on an entire draft standard under any one of the following circumstances:

(a) If the international document is considered to be of little interest to the U.S.

(b) If no U.S. standard, regulation or Federal agency policy exists and there is no intent to develop such.

(c) If no consensus position can be established on the international document.

4.2.4 Exceptions. Exceptions to the above stated voting guidelines should be carefully considered and based on a consensus.

5. Post Meeting Responsibilities. The delegation should prepare a written report to provide basic information with which to evaluate the results of the meeting and to plan for future meetings.

5.1 Report of the Delegation. The head of delegation should be responsible for preparing a report on the meeting within thirty (30) days of the close of meeting. As a minimum, the report should provide the following information:

(a) Title of the meeting, site, and inclusive dates.

(b) Meeting agenda as finally adopted.

(c) List of participants.

(d) Summary of the work of the meeting including titles of draft standards discussed, major issues presented (technical, procedural, or administrative), actions approved, and major positions taken by the delegaticn.

(3) Conclusions of the delegation as regards the wurk and accomplishments of the meeting from the point of view of U.S. interests (e.g.. U.S. positions versus decisions of the meeting as a whole).

(f) Recommendations of the delegation as regards the nature and scope of U.S. participation in future meetings and follow-up actions needed to ameliorate significant problems, particularly those concerning the possible negative impact of any standards requirements on existing or future U.S. trade.

5.2 Distribution of Report. As a minimum the the report should be distributed to the lead agency and to each delegate. When problems of $a$ trade nature have been identified or when the delegation has voted not to approve an entire draft standard based on the voting guidelines in section 4.2 . the report should be sent to the appropriate Technical Office within the Department of Commerce or Department of Agriculture. Circulation of the report should also be made to any U.S. interests that were consulted in the development of positions and. particularly, to U.S. voluntary standards bodies involved in activities related to the subjects covered in the meeling. 
Section II-Guidelines for Participation by U.S. Government Agencies, Employees, or Representatives in International Standards-Related Organizations in which the U.S. Government is not the Official U.S. Member-Body

1. Scope. These guidelines apply to participation by U.S. Government agencies, employees, or representatives in international standards activities in which the U.S. Government is not the official U.S. member-body, such as in the International Organization lor Standardization (ISO) and the International Electrotechnical Commission (IEC). The guidelines supplement OMB Circular No. A-119, "Federal Participation in the Development and Use of Voluntary Standards," which establishes policy to be followed by executive branch agencies in working with voluntary standards organizations.

2. Authorization. In accordance with OMB Circular A-119, agencies and their employees are encouraged to participate in the activities of international standards bodies and standards. developing groups when such participation is in the public interest and is compatible with agencies' missions. authorities, priorities, and budget limitations.

3. Role. U.S. Government agencies and their employees should assist the U.S. member-body in ensuring effective participation and representation of U.S. interests in international standards bodies and standards-developing groups. Such assistance generally falls into one or more of the following types of international standards-related activities.

\subsection{Secretariat of an International} Standards Activity. A U.S. Government agency may be designated by the U.S. member-body to function as secretariat of an international standards committee, subcommittee, working group or task force.

3.2. Administrator/Participant in an Advisory Group. A U.S. Government agency may be requested by the U.S. member-body to function as administrator of an advisory group responsible for coordinating U.S. participation in an international standards activity. Such an advisory group is normally constituted to bring logether all interested parties (public and private) in an international standards activity for the purpose of guiding U.S. participation in that activity. Similarly. agencies or their employees may be asked by the U.S. nrmber-body. or designaled advisnry group administrator, to participate as a member or officer of the advisory group. 3.3. Dclegate to an International Standards Meeting. U.S. Government employees may be invited by the U.S. member-body, or designated advisory group administrator, to participate as a member or head of delegation assembled to represent the memberbody during an international standards committee meeting.

4. Participation Principles. Participation in international standards activities shall be at all times consistent with the highest standards of personal and professional ethirs.

4.1. Decision to Participate. Effective participation in international standards activities outlined in sections 3.1 to 3.3 requires much more effort than merely attending meetings. Before accepting responsibility as secretariat or advisory group administrator of an internationa! standards activity, agencies should thoroughly explore the resource implications and match to mission of such activity and make sure that the work can be undertaken and completed in an effective and timely manner. Likewise, agency employees serving as participants in international standards activities should devote adequate time and effort in preparing for meetings and other related activities to assure the development of meaningful and technically sound standards. The participant should inform his/her supervisor of the estimated time to be devoted to these activities and reach an understanding as to the extent and cost of participation, govemed by individual workload and other official

commitments.

\subsection{Adherence to Policies and}

Procedures of Member Body. In all of the activities listed in 3.1 to 3.3 , agencies and their employees are responsible for adhering to the guidelines and working procedures of both the parent

intemational standards body and the respective U.S. member-body through which their participation is channeled.

4.3. Representing the Public Interest.

Agencies and employees involved in international standards activities should represent the public interest of the United States in the broadest sense. The public interest inolves the interest of those parties who are substantially affected by the standards under consideration and includes manufacturers and producers, industrial users, distributors and retailers, govemment agencies, individual consumers, and the public at large. In serving the public interest, one promotes the general or national welfare rather than the self-interest of private individuals or organizations.
4.4. Consideration of Balnnced Representation. Agencies responsible for administering intemational standards committee secretariats or advisory groups which develop U.S. input to international standards committees should seek a balance of viewpoints. In those cases where an international standard may measurably affect trade, or which may be proposed for adoption as law or regulation within the United States, it is particularly important to seek representation from the affected community (e.8., industry. other agencies, State and local governments, labor, universities, consuming public). Similarly, agency employees who participate on U.S. advisory groups, or as members of U.S. delegations preparing positions on proposed international standards, should offer to assist the responsible parties in assuring that balanced representation has been considered and sought.

4.5. Coordination of Government Viewpoint. There are occasions when Government participants from different agencies are members of the same standards advisory group or serve together as member of a U.S. delegation to an international standards meeting. Generally, their presence is recognition of professional expertise and competence in a particular subject area and/or recognition of differing roles played by their agencies in the subject area. Such participants may even represent different disciplines (chemist versus economist). In such instances it is entirely possible for views to be expressed which are different and which reflect the differing roles of the agencies involved. When this occurs, the participants should try to resolve substantive differences, particularly if they have a bearing on existing law or regulation. If the differences are serious and cannot be resolved by the involved partiripants, they should be brought to the aliention of higher management within the involved agencies.

4.6. Prevention of Trade Barriers. The Government participant should be mindful that a standard may, if improperly written, create an unnecessary barrier to trade. Likewise. the participant should also be aware that some standards may be written in such a way as to impede innovation and technological progress and should strive to provide standards that do not unnecessarily hinder innovative processes and technological advances when they are in the public interest. In general, standards based on performance criteria are less likely 10 pose competitive concerns than design 
material, or construction criteria. Accordingly, preference should be given to performace criterion whenever they reasonably may be used in lieu of design, material, or construction criterion.

4.7. Technical Quality of Standards. It is particularly important that a standard under development is technically sound. within the operating scope of the organization and meets defined needs of the member nations. This may require that the Government representatives consult with other Government experts or with persons in other organizations who are not directly involved with the standard under consideration. Where a standard does not meet a particular set of needs or is not technically sound in the view of the Government participants, he/she should work with the committee to make the necessary corrections. If unsuccessful, the participant should oppose the adoption of the standard and report such action to agency management.

4.8. Voting, When Authorized. In accordance with OMB Cisculis:- A-119, Government participants may vote at each stage of standards development unless specifically prohibited from doing 80 by the head of the agency or that official's designee. The procedures of international standards bodies generally require approval of draft international standards at a number of successive levels (e.g., at the subcommittee. committee, and final or plenary level) before final adoption. The following voting guidelines relate to agency participation in technical advisory groups to international standards committees or in U.S. delegations to international standards committee meetings. The guidelines recognize the policy that U.S. positions relative to international standards activities are developed through a censensus of the participants.

4.8.1 Voting "Yes" to Approve Draft Standards. Subject to the guidelines concerning trade barrier in section 4.6, consider voting "Yes" to approve an entire draft standard under any one of the following circumstances:

(a) If there is a U.S. national standard (a standard generally accepted within the U.S.), or a relevant regulation, or Federal agency policy which can be considered to be equivalent to the international document under consideration.

(b) If any conflict between the internatlonal document and U.S. practice (standard, regulation or policy) is such that the U.S. practice could be modified to conform without losing equivalence. In such cases the affirmative vote should be accompanied by a statement that, "the U.S. affirmative vote recognizes the following minor technical additions, or changes, which may be included in the national standard, regulation or policy.

(c) If no relevant standard, regulation or policy exists and the international document is technically acceptable and could be used to develop national standards.

4.8.2 Voting "No" to Disapprove Draft Standards. Consider voting "No" to not approve an entire draft standard under any one of the following circumstances:

(a) If the international document is considered to be not equivalent to or in clear conflict with a U.A. national standard, regulation or Federal agency policy.

(b) The international document is not technically acceptable.

(c) If a U.S. standard, regulation or policy exists which differs from the international document only because the national practice (standard, regulation or policy) includes additional or more stringent requirements. In such a case, the U.S. vote should be accompanied by comments pointing out that additional requirements must be met to 8 atisfy the national practice.

(d) The international document unnecissarily creates a barrier to domestic or international trade, or impedes innovation or technological progress.

Reasons must be given for a negative vote. The U.S. vote must, therefore, be accompanied by reasons for the negative vote, such as exceptions and/ or additions that will be required to conform with our safety practices or regulations.

4.8.3 Voting 10 "Abstain" on Draft Standards. Consider "Abstaining" on an entire draft standard under any one of the following circumstances:

(a) If the international document is considered to be of little interest to the U.S.

(b) If no U.S. standard, regulation or Federal agency policy exists and there is no intent to develop such.

(c) If no consensus position can be established on the international document.

4.8.4 Exceptions. Exceptions to the above stated voting guidelines should be carefully ronsidered and based on a consensus.

4.8.5 Registering a Dissenting Viewpoint. Government participants may be confronted with the situation where they consider a proposed U.S. vote as being in conflict with the public interest, the interests of the Federal Government, and/or their own professional judgment. Should such a conflict exist, participants should attempt to resolve them within the framework of the advisory group or delegation on which they serve. If unsuccessful, participants should make their position clear in writing to the U.S member-body for the particular standards organization in question and inform their agency of the perceived conflict.

4.9. Patents. While a standard may include a product incorporating a device or process which is patented, it is undesirable for a standard to be written in such a way as to require the use of the patented device or process in order to be in conformance with the standard. Normally this problem can be avoided by writing standurds based on performance criteria rather than design material, or construction criteria. There may be occasions, however, where there is a great need for a particular standard to be written to specify a patented item. Most standards organizations have patent policies which require that if an item which is patented is included in a standard, the owner of a patent must declare that the patent is available for unrestricted licensing under reasonable terms and conditions. Government participants should familiarize themselves with the patent policies of the organizations in which they are participating, and discuss them with their agency counsel should there be any questions.

5. Reports. Government participants who serve as members of U.S. delegations to international standards meetings should prepare a written report on their participation within thirty $(30)$ days after the close of the meeting. Distribution of the report depends upon agency procedures covering such matters. As a minimum, the report should cover important actions and decisions taken during the meeting. Where problems are encountered. particularly as regards a U.S. vote on a standard, participants should consider sending a copy of their report to the appropriate Technical Office identified on page 3.

Guidelines for Federal Agency Use of Private Sector Thind-Party Certification Programs

\section{O. Introduction}

When purchasers receive a product or service, they may seek assurance that it conforms to a specifled standard or specification. The process by which such assurance is provided is referred to as certification. These procedures are intended to provide guidelines for Federal agency acceptance and use of private sector third-party certification. 
APPENDIX F

NIST FORM 83, RECORD OF COMMITTEE ASSIGNMENT 


\section{RECORD OF COMMITTEE ASSIGNMENT}

PLEASE TYPE OR PRINT YOUR RESPONSES - SEE REVERSE FOR INSTRUCTIONS.

1. PUAPOSE (CHECK $Q$ ONE)

NEW MEMBERSHIP

CHANGE INFORMATION PREVIOUSLY SUBMITTED

TERMIMATION OF MEMBERSHIP (COMPLETE BLOCKS 1.9 ONLY)

OTHER (SPECIFY

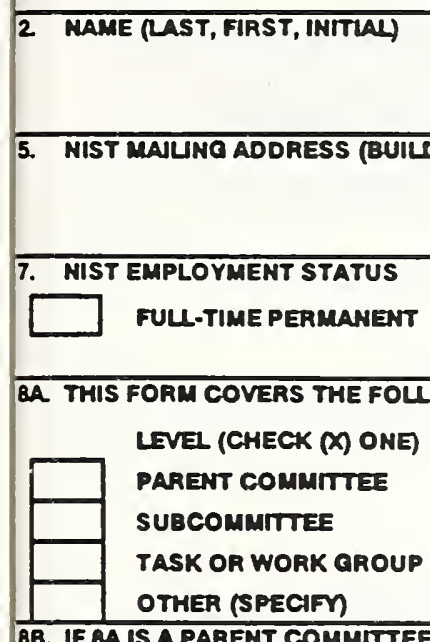

8B. IF BA IS A PARENT COMMITTEE, QO TO 9. IF BA IS A SUBQROUP OF A COMMITTEE (0.9., a subCommitteo or LAEK gROUP), LST THE HIOHER LEVELS BELOW

LEVEL

PARENT COMMITTEE

SUBCOMMITTEE

OTHER (SPECIFY

9. PARENT ORGANIZATION

ANMUITANT

OTHER (SPECIF)

3. ORGAMIZATION CODE

6. NIST TELEPHONE NUMBER

11. DATE OF ASSIONMENT (MONTH/VEAR)

$$
\overline{132}
$$

$$
\begin{aligned}
& \hline \\
& \hline \\
& \hline \\
& \hline
\end{aligned}
$$
MOT ORQANIZATION) (CHECK $(X)$ ONE)

\begin{tabular}{l|l|l}
\hline MATL & "NATL/INTL & INTL \\
\hline
\end{tabular}

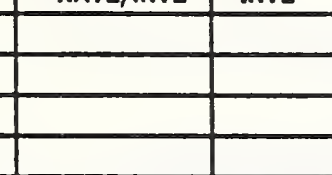

STANDARDS

PROFESSIONAL/SCIENTIFIC/TECHNICAL INTERAGENCY OR PUBUC ADVISORY OTHER (SPECIFY

4. POSITION ON COMMITTEE (CHECK $(x)$ ONE) MEMBER CHALR VCE-CHANR SECRETARY

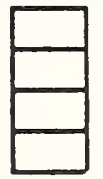

TECHNICAL ADVISOR ALTERMATE REPRESENTATIVE DELCaTE OTHER (SPECIFY)

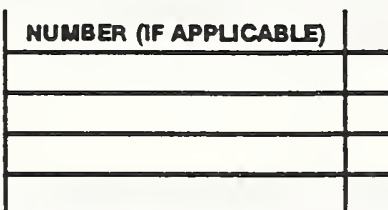

COMPLETE MAME OF ACTIVTY

\begin{tabular}{|l|} 
NUMBER \\
\hline \\
\hline
\end{tabular}

10. SECRETARLAT ORGANIZATION OR COUNTRY
(IF DIFFERENT FROM PARENT ORQANIZATION)

12 EXPIRATION DATE OF ASSIONMENT (IF ANY

138. MATIONAL COMMITTEE WITH MAJOR INTERMATIOMAL RESPONSIBILTIES IF YOU CHECKED NATL/INTL, PLEASE SPECIFY THE INTERNATIONAL COMMITTEE OR COMMITTEES WITH WHICH THE NATIONAL COMMITTEE IS CONCERNED.

\section{VOTINQ STATUS (CHECK $X$ ) ONE)}

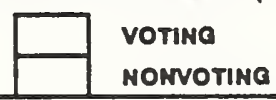

16. TYPE OF FUNDINQ (CHECK $囚$ ONE)

$\square$ NIST

OA (SPECIF)

MIST/OA (SPECIFY AQENCY

OTHER (SPECIFY

KEY WORDS (FOR USE BY COMMITTEE MONITORING OFFICE)

$$
\text { 18. }
$$


INSTRUCTIONS

INTRODUCTION

THIS FORM SERVES AS A RECORD OF MAMAGEMENT APPROVAL OF COMMITTEE ACTIVITIES AND PROVIDES BASIC INFORMATION WHICH IS USED TO COMPILE A DIRECTORY OF STANDARDS COMMITTEE PARTICIPANTS AND A SERIES OF SPECIAL REPORTS FOR NIST MANAGERS AND COMMITTEE PARTICIPANTS. FOR FURTHER INFORMATION, INCLUDINO DEFINITIONS OF TERMS USED ON THIS FORM, REFERENCE AOMINISTRATIVE MANUAL SUBCHAPTER 3.02, STANDARDS AND PROFESSIONAL COMMITTEES. ANY OUESTIONS OR SUGCESTIONS FOR IMPROVNA THIS FORM SHOULD BE DIRECTED TO THE OFFICE OF STANDARDS CODE AND INFORMATION (DMISION 131), WHICH SERVES AS THE NIST COMMITTEE MONTTORINO OFFICE, ADMINISTRATIOH BUILING, ROOM AGZ2,

TELEPHONE EXTEHSION 4035.

QENERAL INFORMATION

1. A SEPARATE FORM SHOULD BE COMPLETED FOR EACH COMMITTEE. FOR EXAMPLE, IF YOU EELONO TO A COMMITTEE AND TWO OF ITS SUBCOMMITTEES, THREE FORMS SHOULD EE FILED OUT.

2. A FORM SHOULD BE FILED AS SOON AS POSSIBLE AFTER JOININO OR APPLYINO FOR MEMBERSHIP ON A COMMITTEE. EMPLOYEES ARE RESPONSIBLE FOR COMPLETINO AND RETURHINO TO THE COMMITTEE OR PANENT ORQAMIZATION ANY FORMS THEY REQUIRE.

3. ADDITIONAL FORMS SHOULO BE FILED TO IMDICATE CHANOES TO THE ORIOINAL FORM, TO REMEW EXPIRED MEMBERSHIPS, AND TO RECORD RESIOMATIONS. FORMS MEED NOT BE FILED FOR INTERMAL NIST COMMITTEES.

4. COPIES AND DISTRIBUTION - THE ORIGINAL AND TWO COPIES OF FORM NIST ES ARE TO EE SENT TO THE DESIONATED INDIMDUALS FOR APPROVAL (SEE APPROVALS).

SPECIFIC COMMENTS

BLOCKS 1.6 - MINOR CHANOES SUCH AS TELEPHONE EXTENSION OR MAIUNO AODRESS MAY DE MADE BY MOTIFYINO THE COMMITTEE MONITORINO OFFICE OY TELEPHONE (EXTENSION 4035) OR MEMO (ADMINISTRATION OUILING, ROOM A620). IF YOU ARE RESIONING FROM A COMMITTEE, COMPLETE ONLY BLOCKS 1.9.

BLOCK 10 - MAME OF AN ORGANIZATION OR COUNTRY ONLY, NOT AN INDMDUAL

BLOCK 11 - IF YOU HAVE BEEN ACCREOITED AS A DELEGATE TO A SPECIFIC MEETING, PUT THE STARTINQ DATE OF THE MEETING IN THIS BLOCK. IF YOU HAVE BEEN ASKED TO SERVE AS A DELEQATE FOR AN INDEFINTTE TIME, PUT THE DATE YOU ACCEPTED THE ASSIONMENT IN THIS BLOCK.

BLOCK $13 A$ - INTERAGENCY COMMITTEE MEANS A COMMITTEE COMPOSED WHOUY OF ENPLOYEES OF TWO OR MORE FEDERAL GOVERNMENT AGENCIES. PUBUC ADVISORY COMMITTEE MEANS ANY COMMITTEE THAT IS (1) ESTABUSHED BY FEDERAL STATUTE OR REORQANIZATION PLAN; (2) ESTABLSHED OR UTILIZED BY THE PRESIDENT; OR (3) ESTABUSHED OR UTILZED BY ONE OR MORE AGENCIES TO OBTAN ADVIE OR RECOMMENDATIONS FOR THE PRESIDENT OR FOR ONE OR MORE FEDERAL GOVERNMENTAGENCIES. THE TERM DOES NOT INCLUDE ANY COMMITTEE WHICH IS COMPOSED WHOUY OF EMPLOYEES OF THE FEDERAL OOVERNMENT.

BLOCK 14 - INDICATE YOUR CURRENT POSITION ON THE ACTIVTYY USTED IM BLOCK \&A. IF YOU SERVE IN MORE THAN ONE CAPACTY, CHECK ONLY THE HIOHEST POSITION HEL.

BLOCK 16 - INDICATE THE ORGANIZATION WHICH PAYS FOR YOUR TIME, TRAVEL, OR OTHER EXPENSES WHEN YOU ARE INVOLVED IN COMMTTEE WORK

BLOCK 17 - DO NOT FILL OUT. FOR COMMITTEE MONITORING OFFICE USE ONLY.

APPROVALS - (FOR FURTHER EXPLANATION OF THE TYPES OF REPRESENTATION, REFERENCE ADMINISTRATIVE MANUAL SUBCHAPTER 3.02, STANDARDS AND PROFESSIONAL COMMITTEES.)

BLOCK 18 -

(1) IF AN MIST TECHNICAL REPRESENTATIVE - SEND THE ORIOINAL AND TWO COPIES OF FORM NIST-B3 TO THE DMISION CHIEF (OR. HIGHER) FOR APPROVAL OMSION CHIEFS AND HIOHER LVVEL MANAQERS SHOUL SION THEIR OWN FORMS. AFTER APPROVAL IS OBTAINED, SEND THE FORM TO THE OFFICE OF STANDARDS CODE AND INFORMATION, WHICH SERVES AS THE NIST COMMITTEE MONITORING OFFICE, FOR PROCESSING.

(2) IF AN OFFICIAL NIST SPOKESMAN - SEND THE ORIOINAL AND TWO COPIES OF FORM NIST B3 WITH A COVER MEMO EXPLAINIMO THE ASSIONMENT THROUOH THE OMSION/CENTER OFFICE TO THE MOU DIRECTOR FOR APPROVAL AFTER APPAOVAL, THE MOU DIRECTOR FORWARDS THE MATERLAL TO THE OFFICE OF STANDARDS CODE AND INFORMATION, WHICH SERVES AS THE NIST COMMITTEE MONITORING OFFICE FOR REVIEW AND FORWARDING TO THE DIRECTOR.

MOTE TO SIONERS - YOUR SIOMATURE INOICATES THAT

(1) THE ACTMITY IS DIRECTLY RELATED TO THE AUTHORIZED FUNCTIONS OF MIST;

(2) THE APPOINTEE IS QUALFIED AND CAN DEVOTE EMOUGH TIME AND EFFORT TO SERVE CREDITABLY; AND

(3) THERE ARE ADEOUATE RESOURCES AVAILABLE OR IN PROSPECT TO SUPPORT MEANINOFUL PANTICIPATION. 
NBS.114A (REV. 2000 )

U.S. DEPT. OF COMM.

BIBLIOGRAPHIC DATA

SHEET (See instructions)

1. PUBLICATION OR

REPORT NO.

NISTIR $89-4204$
2. Performing Organ. Report Nof 3. Publication Date

October 1989

4. TITLE AND SUBTITLE

GUIDELINES FOR NIST STANDARDS COMMITTEE PARTICIPANTS

5. $\operatorname{AUTHOR}(S)$

JoAnne Overman and James Rountree

6. PERFORMING ORGANIZATION (If joint or other than NBS, see instructions)

7. Contracd Grant No.

NATIONAL BUREAU OF STANDARDS

U.S. DEPARTMENT OF COMMERCE

GATTHERSBURG, MD 20899

8. Type of Report \& Period Covered

Final

9. SPONSORING ORGANIZATION NAME AND COMPLETE ADDRESS (Street, City, Stote, ZIP)

10. SUPPLEMENTARY NOTES

Document describes a computer program; SF-185. FIPS Software Summary, is attached.

1. ABSTRACT (A 200-word or less factual summory of most significant information. If document includes a significant bibliography or literature survey, mention it here)

This document provides guidance to NIST employees who participate in voluntary standards development activities of standards bodies. The information provided reflects Federal policy as stated in Office of Management and Budget Circular A-119 as well as NIST policy relating to voluntary standards activities.

12. KEY WORDS (Six to twelve entries; alphabetical order; capitalize only proper names; and separate key words by semicolons) committee participation; SAMI; standards

13. AVAILABILITY

Unlimited

For Official Distribution. Do Not Release to NTIS

$\square$ Order From Superintendent of Documents, U.S. Government Printing Office, Washington, D.C. 20402.

Order From National Technical Information Service (NTIS), Springfield, VA. 22161
14. NO. OF PRINTED PAGES

15. Price 




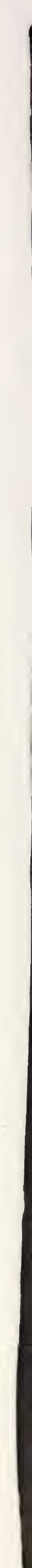

